\title{
BOLITA, an Arabidopsis AP2/ERF-like transcription factor that affects cell expansion and proliferation/differentiation pathways
}

\author{
Nayelli Marsch-Martinez $\cdot$ Raffaella Greco $\cdot$ \\ Jörg D. Becker · Shital Dixit · Jan H. W. Bergervoet · \\ Aarati Karaba $\cdot$ Stefan de Folter $\cdot$ Andy Pereira
}

Received: 8 November 2005 / Accepted: 13 July 2006

(C) Springer Science+Business Media B.V. 2006

\begin{abstract}
The BOLITA (BOL) gene, an $A P 2 / E R F$ transcription factor, was characterized with the help of an activation tag mutant and overexpression lines in Arabidopsis and tobacco. The leaf size of plants overexpressing $B O L$ was smaller than wild type plants due to a reduction in both cell size and cell number. Moreover, severe overexpressors showed ectopic callus formation in roots. Accordingly, global gene expression analysis using the overexpression mutant reflected the alterations in cell proliferation, differentiation and growth through expression changes in $R B R, C Y C D$, and TCP genes, as well as genes involved in cell expansion (i.e. expansins and the actin remodeling factor $A D F 5$ ). Furthermore, the expression of hormone signaling (i.e. auxin and cytokinin), biosynthesis (i.e. ethylene and jasmonic acid) and regulatory genes was found to be perturbed in bol-D mutant leaves.
\end{abstract}

\section{Keywords AP2/ERF transcription factor - Organ size}

Electronic Supplementary Material Supplementary material is available to authorised users in the online version of this article at http://dx.doi.org/10.1007/s11103-006-9059-1.

Nayelli Marsch-Martinez and Raffaella Greco authors contributed equally.

N. Marsch-Martinez · R. Greco · J. D. Becker · S. Dixit ·

J. H. W. Bergervoet $\cdot$ A. Karaba $\cdot$ S. de Folter

A. Pereira $(\square)$

Plant Research International, Wageningen University and

Research Centre, PO Box 16, 6700AA Wageningen,

The Netherlands

e-mail: andy.pereira@wur.nl

J. D. Becker

Centro de Biologia do Desenvolvimento, Instituto Gulbenkian de Ciência, 2780-156 Oeiras, Portugal
- Cell growth - Cell proliferation and differentiation · Cell cycle $\cdot$ CyclinD/retinoblastoma pathway
Introduction

The AP2/ERF transcription factor family is one of the largest in Arabidopsis, comprising of almost 150 genes that are differentially expressed (database of Arabidopsis transcription factors: http://datf.cbi.pku.edu.cn; (Riechmann et al. 2000; Sakuma 2002; Alonso et al. 2003; Kim et al. 2006; Nakano et al. 2006). They have been primarily studied as transcriptional regulators in plants, although proteins that contain the AP2 domain are also coded in the genomes of viruses, cyanobacteria and a ciliate, where they are thought to function as endonucleases (Magnani et al. 2004). The AP2/ERF family members are classified in groups based on the number of AP2/ERF domains and the presence of other domains. AP2 members have two, while ERF members have only one AP2 domain (Riechmann and Meyerowitz 1998). The consensus sequence of the AP2

\begin{tabular}{|l|lll|}
\hline Journal : 11103 & Dispatch : 25-7-2006 & Pages : 19 \\
Article No. : 9059 & $\square$ LE & $\square$ TYPESET \\
MS Code : PLAN1755 & $\checkmark$ CP & $\checkmark$ DISK \\
\hline
\end{tabular}


and the ERF domains are also slightly different, and they have been suggested to belong to distinct families (Okamuro et al. 1997; Riechmann and Meyerowitz 1998; Fujimoto et al. 2000).

While genes belonging to the AP2 family have been shown to play a developmental role, most of the ERF proteins have been studied in relation to biotic and abiotic stress (Riechmann and Meyerowitz 1998). ERFs (Ethylene response factors, also known as EREBP-ERE binding proteins) were first isolated as proteins that could bind to the Ethylene responsive element (ERE) sequence, present in promoters of a number of ethylene-responsive pathogenesis-related (PR) genes (Riechmann and Meyerowitz 1998). The EREBP/ERF domain has been shown to bind the GCC box in promoters of tobacco genes and to regulate genes containing the GCC box in Arabidopsis (Allen et al. 1998; Fujimoto et al. 2000). The study of five Arabidopsis ERF genes by Fujimoto and colleagues showed that they could act either as transcriptional activators or repressors (Fujimoto et al. 2000).

Interestingly, some members of the ERF subfamily in Arabidopsis, i.e. TINY and DORNROSCHEN/ ENHANCER OF SHOOT REGENERATION1 (DRN/ESR1), have not been described in context to stress, but have been rather related to developmental roles. In the case of TINY, its overexpression leads to plants that have organs of reduced size, due to a reduction in cell elongation (Wilson et al. 1996). $D R N /$ ESR1 overexpression enhances shoot regeneration from roots and leads to shoot apical meristem consumption (Banno et al. 2001; Kirch et al. 2003).

Leaf development requires the co-ordinated activity of genes that determine dorsoventrality of the primordia, switch from indeterminate to determinate growth, and regulate cell cycling and cell elongation (reviewed in Tsukaya 2005). Organ size is finally determined by cell size in combination with cell number (Mizukami 2001). Cell size increases through cell expansion, and is affected by alterations in cell wall biosynthesis enzymes and remodeling proteins like expansins (reviewed in Fleming 2006), cytoskeleton (Smith 2003; Wasteneys and Fujita 2006), and nuclear DNA content, which can be increased by endoreduplication (Sugimoto-Shirasu and Roberts 2003). Other factors, like sterols and hormones also affect cell growth (Timpte et al. 1992; Kieber et al. 1993; Klahre et al. 1998; Schrick et al. 2004). Cell proliferation, closely linked to the cell cycle, is controlled by different genes (e.g. AINTEGUMENTA, an AP2 gene, ARGOS, an auxin regulated gene, and TCP genes among others
(Mizukami and Fischer 2000; Mizukami 2001; Hu et al. 2003; Nath et al. 2003). Like for cell expansion, changes in hormonal pathways also affect cell proliferation, leading to altered cell numbers (reviewed in Dewitte and Murray 2003). Auxin in particular has broad effects in plants and is also important in leaf development, since its accumulation leads to leaf formation in the apical meristem (Kuhlemeier and Reinhardt 2001). Transcription factors play an important role in hormone signal transduction, and they interconnect different hormone pathways (Vogler and Kuhlemeier 2003). Key effects of hormones in development have been found to be mediated by transcription factors. The PLETHORA genes mediate root stem cell specification in response to auxin (Aida et al. 2004), and WUSCHEL controls shoot meristem function by direct regulation of the cytokinin-inducible response regulators ARR5, ARR6, ARR7 and ARR15 (Leibfried et al. 2005).

The processes of cell proliferation and differentiation are balanced by cell cycle regulators together with other genes (reviewed in Ramirez-Parra et al. 2005). For example, the cell cycle component RBR1 (Retinoblastoma-related protein) has been shown to control nuclear proliferation in the female gametophyte and to regulate stem cell fate in the root (Ebel et al. 2004; Wildwater et al. 2005).

Here, we describe the characterization of BOLITA $(B O L)$, an Arabidopsis AP2/ERF like gene that affects cell proliferation and size, which when overexpressed in Arabidopsis leads to reduced organ size and affects cell differentiation, inducing the formation of ectopic green callus in roots. Some of its effects might be due to both perturbations of cell cycle regulators like RBR1, CyclinD and TCP (named after teosinte branched 1, cycloidea and pcf1 and 2) genes and hormone signaling alterations.

\section{Materials and methods}

Mutant identification

The original bolita (bol-D) mutant was first identified as a leaf mutant in a collection of plants with stable activation tag transposon insertions in ecotype Wassiliewskija (Ws) (Marsch-Martinez et al. 2002). A single plant with the bolita phenotype was observed among the progeny of the original parental line. Seed obtained from self-fertilized plants were sown in soil in the greenhouse and the number of plants showing the bolita or wild type phenotype scored.

\begin{tabular}{|c|c|c|c|}
\hline & Journal : 11103 & Dispatch : 25-7-2006 & Pages: 19 \\
\hline 믹 & $\begin{array}{l}\text { Article No. : } 9059 \\
\text { MS Code : PLAN1755 }\end{array}$ & $\begin{array}{l}\square \mathrm{LE} \\
\nabla_{\mathrm{CP}}\end{array}$ & $\begin{array}{l}\square \text { TYPESET } \\
\Downarrow \text { DISK }\end{array}$ \\
\hline
\end{tabular}


Plant growth day.
Arabidopsis seeds received a cold treatment $\left(4^{\circ} \mathrm{C}\right.$ for at least 3 nights) in a wet filter paper in petri dishes before being sown in soil. Plants were grown in the greenhouse at $22^{\circ} \mathrm{C}$, mostly during long day conditions. Tobacco (Nicotiana tabacum cv SR1) plants were transferred from medium to soil and grown in a temperature-controlled greenhouse.

For transformant selection, Arabidopsis seeds were surface sterilized with bleach, and sown in medium containing $1 / 2 \mathrm{MS}, 50 \mathrm{mg} / \mathrm{l} \mathrm{kanamycin,} 1 \%$ sucrose, $0.8 \%$ purified agar. For phenotypic analysis of seedlings, medium lacking kanamycin, with $1 \%$ agarose was used. The plates used for these analyses were placed almost vertically in the growth chamber. Plates were kept at $4^{\circ} \mathrm{C}$ for at least 3 nights before transferring to the growth chamber. Tobacco seeds were sown in MS medium containing 3\% sucrose and $1 \%$ agarose. Both plants were grown in a growth chamber at $22-23^{\circ} \mathrm{C}$, with $16 \mathrm{~h}$ of light per

\section{DNA analysis and plant transformation}

The isolation of the sequence flanking the transposon was done by TAIL-PCR (Liu and Whittier 1995; Tsugeki et al. 1996) as described in (MarschMartinez et al. 2002). The BOLITA coding sequence (At1g24590) was amplified from Ws genomic DNA by PCR using the following primers: EREBPXba: 5'-TAT ATC TAG AAG GTC AAC CAT GGA AGA AGC-3' and EREBP-Sst: 5'-TAT AGA GCT CTT GTC TTC ATC CAG CAC CTC-3'. The PCR was performed using Pfu polymerase (PfuUltra, Stratagene) with the following conditions: $94^{\circ} 3^{\prime}$, $\left(94^{\circ} 1^{\prime}, 60^{\circ} 1^{\prime}, 72^{\circ} 2^{\prime} 30^{\prime \prime}\right) 35$ cycles, $72^{\circ} 10^{\prime}$. The $1.2-\mathrm{kb}$ product was cloned first into the pGEM-T easy (Promega) and then directionally behind the CaMV35S promoter in a modified pBI121 binary vector (Clontech). For the BOL promoter-GUS fusion, a $1550 \mathrm{bp}$ DNA sequence upstream of the predicted translation start was also amplified by PCR from genomic Ws DNA. The following primers were used: AP2-p-Xba F: 5'-TAA TCT AGA GCT CAC GAC TTC TCT TCC TTC- $3^{\prime}$ and AP2p-Nco R: 5'-ATT GCT TCT TCC ATG GTT GAC CT- $3^{\prime}$. The fragment was subsequently cloned into pGEM-T easy and then in front of the GUS gene in the pBINplus vector (Engelen et al. 1995). Both constructs were transformed in A. tumefaciens C58 for Arabidopsis and tobacco transformation. The constructs were introduced into Arabidopsis, ecotype Ws using the floral dip method with some modifications (Clough and Bent 1998). Tobacco (Nicotiana tabacum) transformations were done as described (Horsch et al. 1985; Mlynarova et al. 1994).

RNA isolation and gene expression analysis

RNA was isolated using either $\mathrm{LiCl}$ (Verwoerd et al. 1989), Trizol reagent, following the protocol supplied by the provider (Life Technologies) or with the QIAGEN RNeasy plant mini kit. Around $1 \mu \mathrm{g}$ RNA was treated with DNAse I (Invitrogen), and 1/10 of the treated RNA was used for cDNA synthesis with M-MLV Reverse Transcriptase or Superscript II Rnase H-Reverse Transcriptase (both from Invitrogen), following the supplier's instructions.

The cDNA obtained was used for gene expression analysis. PCR were performed using cDNA from wild type and mutant tissues (wild type roots, rosette leaves, cauline leaves, stem, flower buds, flowers; mutant roots, rosette leaves, cauline leaves and flowers; and leaves from $B O L$ overexpression lines -A, -B, and $-\mathrm{C})$. The reactions were performed in the following conditions: $94^{\circ} \mathrm{C} 3^{\prime},\left(94^{\circ} \mathrm{C} 30^{\prime \prime}, 60^{\circ} \mathrm{C} 1^{\prime}, 72^{\circ} \mathrm{C}\right.$ $\left.2^{\prime}\right) 35$ or 40 cycles, $72^{\circ} \mathrm{C} 10^{\prime}$. The following primers for the $B O L$ gene were used: EREBP-Xba: 5'-TAT ATC TAG AAG GTC AAC CAT GGA AGA AGC-3'; and BL-AP2-R2: 5'-CAA TAC TGA TAA AAC ATT CCA CCAT-3'. A PCR using ACTIN primers for all the samples was used as a control. The reaction was performed as follows: $94^{\circ} \mathrm{C} 3^{\prime},\left(94^{\circ} \mathrm{C}\right.$ $\left.30^{\prime \prime}, 55^{\circ} \mathrm{C} 1^{\prime}, 72^{\circ} \mathrm{C} 2^{\prime}\right) 35$ cycles, $72^{\circ} \mathrm{C} 10^{\prime}$. The primers were: Actin-forward: 5'-GTGTTGGACTCTGGAGATGGTGTG $-3^{\prime} ;$ and Actin-reverse 5'GCCAAAGCAGTGATCTCTTTGCTC-3'.

Analysis of an insertion line containing an insertion in the $B O L$ gene

A Ler line containing multiple $I$ element insertions was used to study the effects of gene disruption. The line was identified as containing the Inhibitor Tagged Site 75 (Speulman et al. 1999), indicating an insertion in the At1g24590 exon. The position of the insertion is near nucleotide 775 in the only exon of the gene. The plants were assayed with primers itir3 (5'CTTACCTTTTTTCTTGTAGTG-3') and EREBP$\mathrm{Xba}$ for the presence of the insertion, and with primers EREBP-Xba and EREBP-Sst to assess for plant homo or heterozygosis.

\begin{tabular}{|c|c|c|c|}
\hline & Journal : 11103 & Dispatch : 25-7-2006 & Pages: 19 \\
\hline & $\begin{array}{l}\text { Article No. : } 9059 \\
\text { MS Code : } \quad \text { PLAN1755 }\end{array}$ & $\begin{array}{l}\square \mathrm{LE} \\
\boldsymbol{V}_{\mathrm{CP}}\end{array}$ & $\begin{array}{l}\square \text { TYPESET } \\
\checkmark \text { DISK }\end{array}$ \\
\hline
\end{tabular}


Histological analysis and GUS staining

Impressions of leaf epidermis were done either using foam dissolved in xylene or domestic nail polish (HEMA, The Netherlands) for Arabidopsis leaves. The liquid solution or polish was applied to the adaxial surface of tobacco and Arabidopsis leaves. The dry layer was removed after 3-15 min and observed under a light microscope. Arabidopsis rosette leaves from 5 weeks old bol-D and wild type plants were used. The adaxial epidermis of the middle region of the leaves was analyzed at $40 \times$ magnification. GUS staining of all lines was done overnight at $37^{\circ} \mathrm{C}$ in a standard $\mathrm{X}$-gluc solution (Gallaher 1992).

\section{Hormone and etiolation experiments}

Seed were treated at $4^{\circ} \mathrm{C}$ for 3 nights and the seedlings grown in a $22^{\circ} \mathrm{C}$ growth chamber. The "basic" medium used was $1 / 2 \mathrm{MS}, 1 \%$ sucrose, $1 \%$ agarose. Two sets of experiments were done. In the first, seed were directly germinated in medium supplemented with hormones (EBR-Epibrasinolide, $5 \mathrm{nM}$; BL2223-Brassinolide, $5 \mathrm{nM}$; BAP-Benzyl amino purine, $0.5 \mathrm{uM}$; Kinetin, $0.5 \mathrm{uM} ; \mathrm{GA}_{3}$-Gibberellin, $0.5 \mathrm{uM}$; and IAA-Indole-3-acetic acid, $0.5 \mathrm{uM}$, and no hormones). These seedlings were observed after 7, 11, and 33 days. In the second set, seed were first germinated in medium without hormones, and then transferred after 5 days to medium supplemented with hormones (NAA-1-Naphthaleneacetic acid, $100 \mathrm{nM}$; Kinetin, $5 \mathrm{uM}$; IAA, $5 \mathrm{uM}$; and no hormones). The seedlings were observed just before transfer, 6 days and 25 days after transfer.

The etiolation experiments were done by placing the stratified plates for 3 days in dark conditions in halfstrength MS, $0.8 \%$ or $0.7 \%$ agar medium supplemented with STS $0.1 \mathrm{mM}$, AVG $5 \mathrm{uM}$, and ACC $5 \mathrm{uM}$ or not supplemented. For the spraying experiments in the greenhouse, $\mathrm{GA}_{3}$ was dissolved in $1 \mathrm{mM} \mathrm{KOH}$, and diluted further with water, a $100 \mathrm{mM}$ solution containing triton was used. The plants were sprayed just before flowering (before 4 weeks after sowing) and twice a week onwards.

\section{Flow cytometry}

Pieces of the internal area (closest to the middle vein) or to the edge of wild type and $35 S-B O L$ tobacco leaves were chopped in $1 \mathrm{ml}$ PBS buffer ( $\mathrm{pH}$ 6.8). The suspension was passed through a $50 \mu \mathrm{m}$ mesh and $20 \mu \mathrm{l}$ propidium iodine/ml was added. After $10 \mathrm{~min}$ the DNA content per nucleus was measured using a
Beckman Coulter Epics XL-MCL flow cytometer. Different experiments were performed using independent samples, and to each sample isolated nuclei of tomato seeds or sunflower embryos were added as internal markers for DNA content.

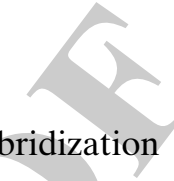

to Affymetrix GeneChips

Total RNA was isolated using the RNeasy plant mini kit (Qiagen, Hilden, Germany). The plants were grown under normal greenhouse conditions $\left(23-25^{\circ} \mathrm{C}, 14 \mathrm{~h}\right.$ light). The youngest leaves larger than $2 \mathrm{~mm}$ emerging from the rosette of 4 weeks old plants were used. For the biological replicates, 3-4 mutant or two wild type leaves from different plants were pooled for one sample, and the same amount from different plants for the second sample.

Concentration and purity was determined by spectrophotometry and integrity was confirmed using an Agilent 2100 Bioanalyzer with a RNA 6000 Nano Assay (Agilent Technologies, Palo Alto, CA). Each GeneChip experiment was performed with biological duplicates. The hybridizations were performed at the Affymetrix Core Facility in the Instituto Gulbenkian de Ciência (Oeiras, Portugal). RNA was processed for use on Affymetrix (Santa Clara, CA, USA) Arabidopsis ATH1 Genome Arrays, according to the manufacturer's OneCycle Target Labeling Assay. Briefly, $2.5 \mu \mathrm{g}$ of total RNA containing spiked in Poly-A RNA controls (GeneChip Expression GeneChip Eukaryotic Poly-A RNA Control Kit; Affymetrix) was used in a reverse transcription reaction (One-Cycle DNA synthesis kit; Affymetrix) to generate first-strand cDNA. After second-strand synthesis, double-stranded cDNA was used in an in vitro transcription (IVT) reaction to generate biotinylated cRNA (GeneChip Expression 3'-Amplification Reagents for IVT-Labeling; Affymetrix). Size distribution of the cRNA and fragmented cRNA, respectively, was assessed using an Agilent 2100 Bioanalyzer with a RNA 6000 Nano Assay. Ten micrograms of fragmented cRNA was used in a $200-\mu$ l hybridization containing added hybridization controls for $16 \mathrm{~h}$ at $45^{\circ} \mathrm{C}$. Standard post-hybridization wash and doublestain protocols (EukGE-WS2v4) were used on an Affymetrix GeneChip Fluidics Station 400. Arrays were scanned on an Affymetrix GeneChip scanner 3000.

GeneChip data analysis

Scanned arrays were analyzed first with Affymetrix MAS 5.0 software to obtain Absent/Present calls and
299

300 340

\begin{tabular}{|l|lll|}
\hline Journal : $\mathbf{1 1 1 0 3}$ & Dispatch : 25-7-2006 & Pages : 19 \\
Article No. : $\mathbf{9 0 5 9}$ & $\square$ LE & $\square$ TYPESET \\
MS Code : PLAN1755 & $\checkmark$ CP & $\square$ DISK \\
\hline
\end{tabular}


subsequently with DNA-Chip Analyzer (dChip) Version 1.3 (http://www.dchip.org, Wong Lab, Harvard). The arrays were normalized to a baseline array with median CEL intensity by applying an Invariant Set Normalization Method ( $\mathrm{Li}$ and Wong 2001b). Normalized CEL intensities were used to obtain model-based gene expression indices based on a PM (Perfect Match)only model ( $\mathrm{Li}$ and Wong 2001a). Replicate data for the same sample type were weighted gene-wise by using inverse squared standard error as weights. Only genes called Present in at least one of the four arrays and within replicate arrays called Present within a variation of $0<$ Median (Standard Deviation/Mean) $<0.5$ were kept for downstream analysis (14.474 genes). Thus, genes called Absent in all arrays and genes with highly inconsistent expression levels within replicate arrays were excluded. All genes compared were considered to be differentially expressed if the $90 \%$ lower confidence bound of the fold change between experiment and baseline was above 1.3 (Median false discovery rate of $0 \%$ ). The lower confidence bound criterion means that we can be $90 \%$ confident that the fold change is a value between the lower confidence bound and a variable upper confidence bound. Li and Wong (2001a, b) have shown that the lower confidence bound is a conservative estimate of the fold change and therefore more reliable as a ranking statistic for changes in gene expression (Li and Wong 2001a).

Annotations for the 22.750 genes represented on the Arabidopsis ATH1 Genome Array were obtained from the NetAffx database (www.affymetrix.com) as of April 2005 and imported into dChip using ChipInfo software (Zhong et al. 2003). All GeneChip datasets are available in a MIAME-compliant format through ArrayExpress (Accession No. XXX).

Upon request, all novel materials described in this publication will be made available in a timely manner for non-commercial research purposes, subject to the requisite permission from any third-party owners of all or parts of the material. Obtaining any permission will be the responsibility of the requestor.

\section{Results}

\section{Mutant identification and description}

An Arabidopsis mutant with a rosette of reduced size and extremely short stem (Fig. 1A, B, E and F) was identified from an En-I transposon activation tagging population (Marsch-Martinez et al. 2002). The mutant was named "bolita" (bol-D), which means "small ball" in Spanish. Segregation analysis of bol-D selfings or crosses to wild type revealed wild type and mutant plants of varied severity and suggested that the mutation was semi-dominant. Among the selfed progeny, mutant plants of different sizes were observed to segregate, ranging from medium-sized plants (with a rosette diameter larger than $1 \mathrm{~cm}$ ) to some extremely small plants (less than $0.5 \mathrm{~cm}$ in diameter), most probably homozygotes (Supplementary Fig. 1G). The original mutant plant and selfed progeny had small epinastic (curved downwards) rosette and cauline leaves without petioles (Fig. 1A, B and F). The leaves could not be flattened without folding or cutting the lamina, as occurs with surfaces having positive Gaussian curvature (Nath et al. 2003).

Moreover, stem elongation was severely affected in the bol mutant, resulting in a mature plant height of about $3 \mathrm{~cm}$ (Fig. 1B), representing more than 10-fold reduction compared to a 6 weeks old wild type plant (Fig. 1B and Supplementary Fig. 1J).

Bol-D flower buds were therefore compacted in a short axis (Fig. 1B and Supplementary Fig. 1C, D, I and J). They were rounder and smaller than wild type buds and they opened later, though the flowering time was not affected. Mature flowers of young plants had shorter, sometimes greenish petals and shorter anthers with no visible pollen (Fig. 1C and Supplementary Fig. 1H). In older plants, the flowers recovered the wild type petal and anther phenotype, but they had reduced male fertility. Therefore, whenever necessary, crosses were done using bol- $D$ as the female parent. In spite of the reduced fertility, the medium-sized mutant progeny plants produced some selfed seed when allowed to grow for longer times than wild type plants. The siliques of the mutant remained shorter and broader than wild type, some being club-shaped (Supplementary Fig. 1F). Most of them were partially empty and contained less than half the normal amount of seeds, both in the case of crosses or selfings. In extreme cases, only one or two seeds were present. Moreover, bol-D seeds were larger than wild type seeds (Supplementary Fig. 1K). Finally, though roots were not strongly affected 1 week after germination, after 15 days they showed a decrease in the number of lateral roots when compared to wild type plants (Fig. 1D).

Reduction in cell size and number in the bol-D leaves

Leaf size depends both on cell size and cell number. Therefore, both parameters were analyzed in the small sized bol-D leaves. First, to assess whether cell size was affected, the epidermis was imprinted and observed

\begin{tabular}{|c|c|c|c|}
\hline & Journal : 11103 & Dispatch : 25-7-2006 & Pages: 19 \\
\hline & $\begin{array}{l}\text { Article No. : } 9059 \\
\text { MS Code : PLAN1755 }\end{array}$ & $\begin{array}{l}\square \mathrm{LE} \\
{ }_{\mathrm{CP}}\end{array}$ & $\begin{array}{l}\square \text { TYPESET } \\
\Downarrow \text { DISK }\end{array}$ \\
\hline
\end{tabular}



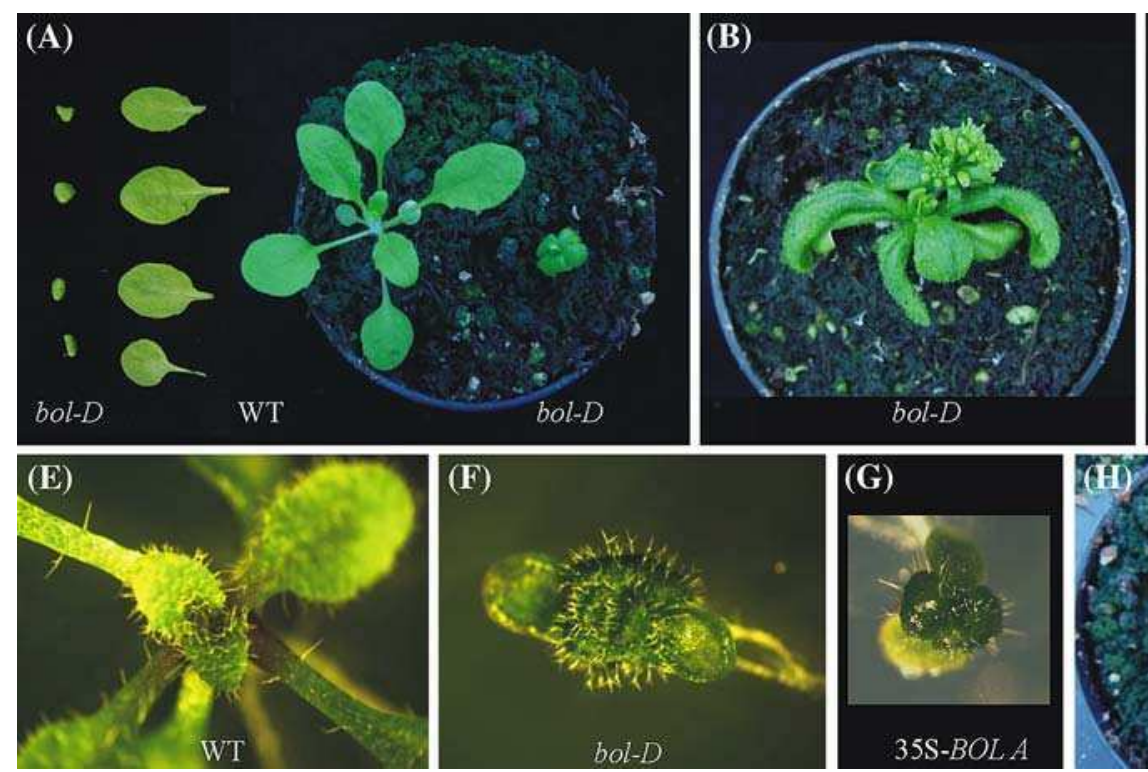

Fig. 1 Phenotypes of the original gain of function bol-D mutant and $35 \mathrm{~S}-\mathrm{BOL}$ lines. (A) Comparison of bol-D and wild type rosette leaves and soil grown wild type Ws and bol-D plants, just flowering. (B) Mature bol-D plant (older than 4 weeks) showing extremely reduced elongation of the main stem, while a wild type plant had a height of at least $30 \mathrm{~cm}$ (not shown). Sometimes, the

442

443

444

445

446

447

448

449

450

451

452

453

454

455

456

457

458

459 under a light microscope. Interestingly, imprints from Arabidopsis bol-D leaves revealed cells of reduced size in comparison to wild type leaf cells (Table 1; Fig. 2A and $\mathrm{B})$. The reduction in leaf size observed among segregating bol-D progeny correlated with the reduction of cell size, as leaves of smaller bol-D plants had smaller cells than leaves of medium-sized bol-D plants.

Next, the number of cells per leaf was determined (Table 1) in wild type Ws and bol-D plants. In the examined leaves, wild type leaf area was about 5.7 times larger than bol-D leaf area. The density of bol-D cells was almost three times the density of wild type cells, and remarkably, the total number of cells per leaf was only the half. Therefore, both cell size and cell number reduction led to the smaller leaf size in bol- $D$ mutants.

Since some mutants affected in hormone pathways resemble the bol-D phenotype (i.e. dwarfism caused by
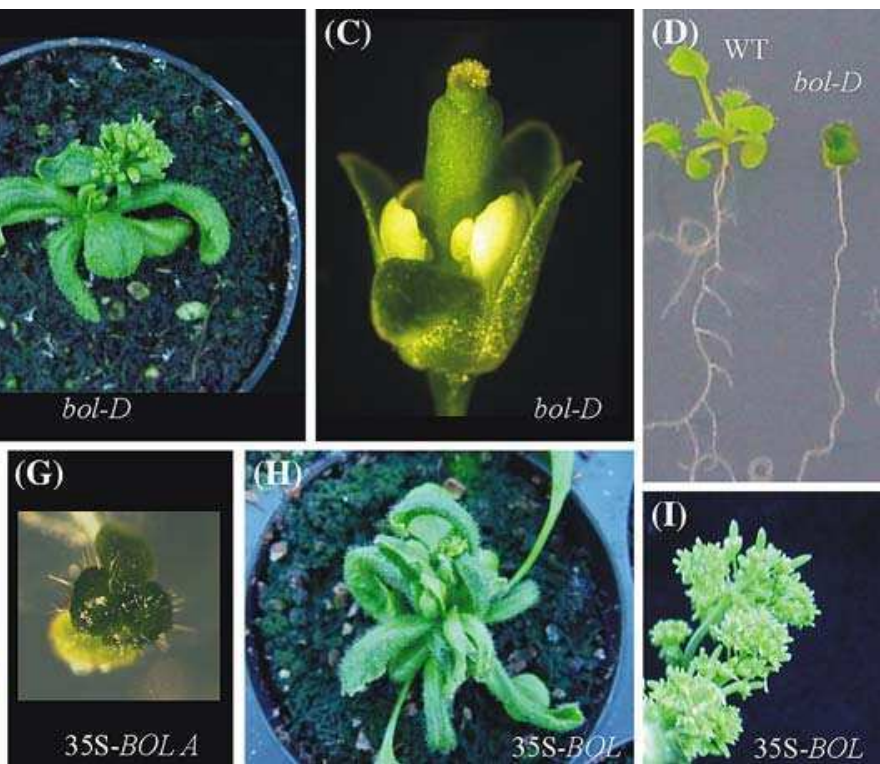

first leaves elongated spirally. In general, leaves senesced slowly and the oldest leaves were thick, with severe curling that caused breaks in the leaf lamina (C), bol-D flower. (D) In vitro grown wild type and bol-D plants. bol-D roots have less lateral roots than wild type. $(\mathbf{E}-\mathbf{G})$ In vitro grown wild type $(\mathbf{E})$, bol- $D(\mathbf{F})$, and $35 \mathrm{~S}-B O L-\mathrm{A}(\mathbf{G})$ young plants. (H) Mature $35 \mathrm{~S}-\mathrm{BOL}$ plant.

brassinosteroid or gibberellin deficiencies (Helliwell et al. 1998; Choe et al. 2000), we tested whether hormone application would restore its leaf phenotype. None of the hormone treatments given in the conditions tested restored the leaf phenotype (See Supplementary text). However, while gibberellin sprayed to greenhouse grown plants at flowering time did not restore leaf expansion or stem elongation, it resulted in the earlier elongation of petals and anthers of bol-D flowers (Supplementary Fig. 1I and J).

Molecular analysis and gene isolation

Southern blot analysis of the bol-D activation tag mutant showed a single transposon insertion present in the genome. Isolation, sequencing of the flanking DNA, and comparison to the Arabidopsis genome sequence using BLAST (Altschul et al. 1997), revealed
470

471

472

473

474

475

Table 1 Cell density, size and number in mature leaves

\begin{tabular}{llll}
\hline $\begin{array}{l}\text { Plant line } \\
\text { (Arabidopsis) }\end{array}$ & $\begin{array}{l}\text { Pavement cell density } \\
\left(\text { cells/mm } \mathrm{mm}^{2} \pm \mathrm{SD}\right)\end{array}$ & $\begin{array}{l}\text { Average cell size } \\
\left(\mu \mathrm{m}^{2} \pm \mathrm{SD}\right)\end{array}$ & $\begin{array}{l}\text { Cell number } \\
\text { per leaf }( \pm \mathrm{SD})\end{array}$ \\
\hline Wild type & $140.625 \pm 18.60$ & $7214 \pm 896$ & $43031 \pm 5691$ \\
bol- $D$ & $403.12 \pm 33.90$ & $2496 \pm 210$ & $21688 \pm 1824$ \\
Ratio bol-D:Ws & 2.87 & 0.35 & 0.5 \\
\hline
\end{tabular}

The data represents eight measurements from the middle region of mature rosette leaves (adaxial epidermis) of WT and bol-D soil grown plants

\begin{tabular}{|l|lll|}
\hline Journal : $\mathbf{1 1 1 0 3}$ & Dispatch : 25-7-2006 & Pages : 19 \\
Article No. : $\mathbf{9 0 5 9}$ & $\square$ LE & $\square$ TYPESET \\
MS Code : PLAN1755 & $\checkmark$ CP & $\square$ DISK \\
\hline
\end{tabular}


Fig. 2 Comparison of wild type Arabidopsis leaf epidermal cells to bol-D leaf cells. (A and $\mathbf{B}$ ) Epidermal cells of bol-D (A) and wild type (B) Arabidopsis leaves (both mature rosette leaves). (C) Dark germinated seedlings of different 35S$B O L$ lines compared to wild type seedlings showing altered etiolation response at different degrees
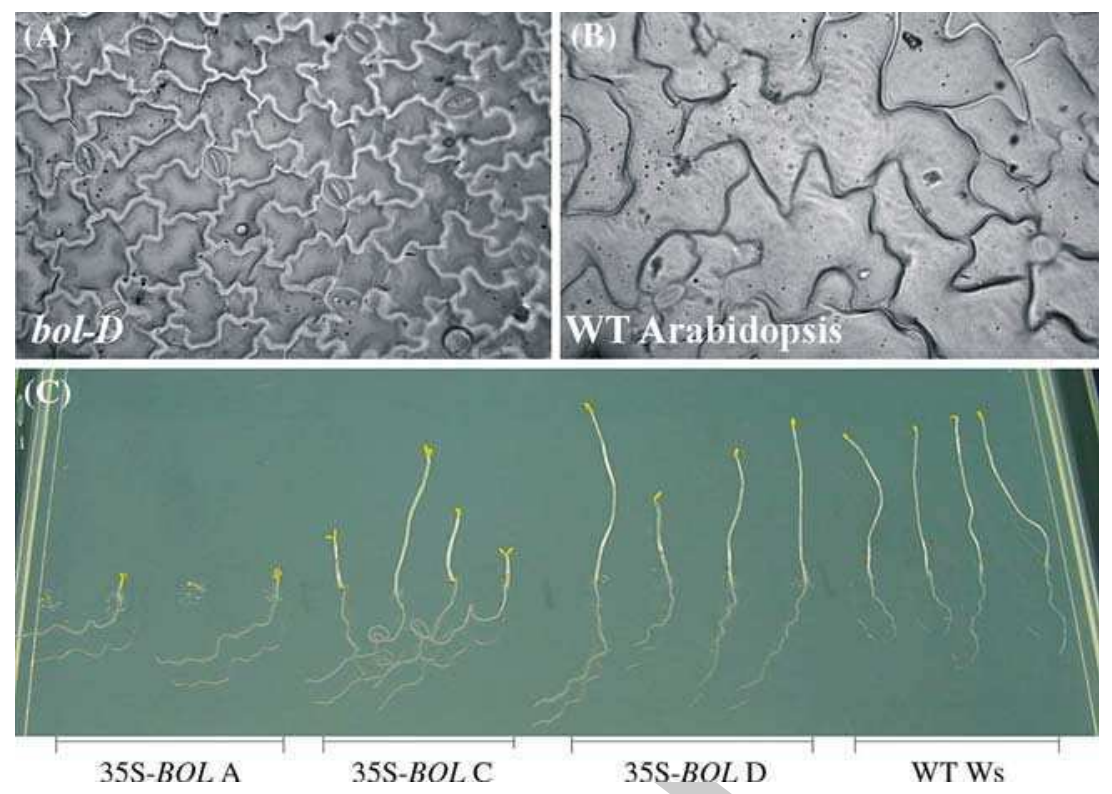

that the insert was present on chromosome I, between two predicted genes transcribing outwards with respect to the insertion (Fig. 3A). The translation start of the nearer gene (At1g24590), encoding a putative AP2/ ERF transcription factor, was situated $600 \mathrm{bp}$ away from the right border of the transposon insert. The more distant gene (At1g24600), annotated as an expressed protein, was situated $4.5 \mathrm{~kb}$ from the left border, adjacent to the transposon end bearing the $35 \mathrm{~S}$ enhancer tetramer.

RT-PCR experiments were then performed to assess expression of AP2/ERF gene At1g24590, representing the best candidate based on the position of the insert in the activation tag mutant and the nature of the gene itself. While in wild type plants the presence of its transcript was detected only in flower buds, in the bol-D mutant hyper-accumulation of this transcript occurred in roots, rosette and cauline leaves, flowers buds and open flowers (Fig. 3B). This intronless gene, henceforth named BOLITA $(B O L)$, was predicted to encode a 306 aa protein that belongs to the ERF family, as it contains a single AP2/ERF domain. The closest homolog of BOL in the Arabidopsis genome is DRN/ESR1, which led to it being referred to as DRNlike (Kirch et al. 2003). To test whether the change in expression of this gene was causing the observed bol-D phenotype, an overexpression construct with the $B O L$ coding sequence driven by the $35 \mathrm{~S}$ promoter $(35 \mathrm{~S}$ $B O L$ ) was introduced into wild type Arabidopsis and tobacco plants. The plants containing the overexpression construct showed leaves with the bol-D leaf phenotype (Figs. 1E-I and $4 \mathrm{~B}$ and $\mathrm{F}$ ) suggesting that $B O L$ overexpression was indeed causing it.
Gene expression analysis in Arabidopsis

The RT-PCR experiment previously described showed that $B O L$ transcript accumulation occurred mainly in flower buds in wild type plants, and was not detected in other tissues in the conditions tested (Fig. 3B). In addition, a BOLpromoter-GUS construct was used to study further the temporal and spatial pattern of expression. In plants containing the construct, GUS staining was detected at different stages of development (Fig. 5A-D and Supplementary Fig. 2A and B). In the first 2 days after germination, staining occurred at the shoot apical meristem (SAM, Fig. 5A and B) in 5 out of 6 independent transfomants, and at the distal regions of the cotyledons and the inner cell layers of the root meristematic zone (Fig. 5B and Supplementary Fig. 2A) in 3 and 2 lines, respectively. The root expression pattern, both in primary and secondary roots, was also observed in older plants. Five days after germination, seedlings showed mild staining at the SAM and intense staining at leaf primordia (Fig. 5C). Emerging leaves from older seedlings stained first at the tip and later at separated spots at the leaf periphery (hydatodes). Mature plants also showed staining at young axillary buds (Fig. 5D) and the internal organs of young flower buds, confirming the RT-PCR results and in accordance with in situ hybridization data reported by Kirch and colleagues for $D R N$-like, showing expression in young petals and stamens (Kirch et al. 2003). In mature flowers, half of the BOL-GUS lines showed stained anthers. Moreover, $B O L$ appeared to be expressed in the embryo and seed according to a study analyzing gene expression during fruit develop-

\begin{tabular}{lll} 
Journal : 11103 & Dispatch : 25-7-2006 & Pages : 19 \\
Article No. : 9059 & $\square$ LE & $\square$ TYPESET \\
MS Code : PLAN1755 & $\checkmark$ CP & $\square$ DISK \\
\hline
\end{tabular}




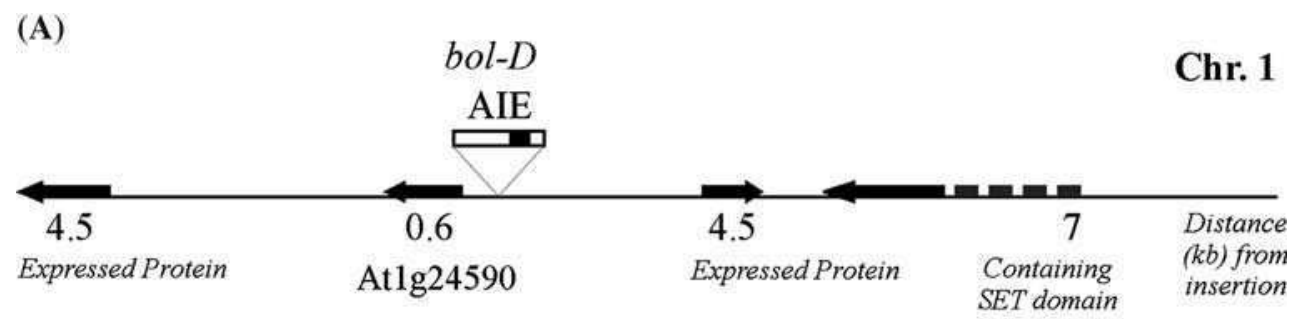

(B)

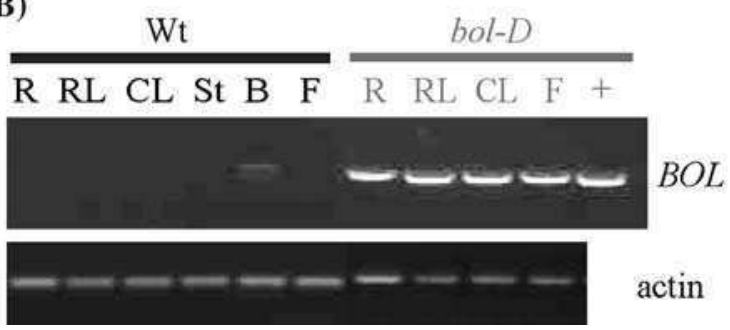

Fig. 3 Position of the Activating I Element (AIE) in bol-D, and expression analysis of adjacent gene. (A) AIE insertion in the bolita mutant, the dark box inside the "insertion" represents the 35S enhancer tetramer. (B) Semi-quantitative RT-PCR analysis of the AP2-ERF-like gene next to the AIE insertion. The RT-

541

542

543 ment (de Folter et al. 2004). Unfortunately, neither $B O L$ nor $D R N$, its closest homolog, are represented in Affymetrix chips, and therefore the accumulating expression data in public databases could not be used.

Analysis of an insertion mutant in the $B O L$ gene

In order to assess the effect of the $B O L$ loss of function, a plant containing a transposon insertion in the gene was studied. T-DNA insertions within the $B O L$ coding region were not available. The transposon insertion was identified with the adjacent sequence ITS75 in a multiple I-dSpm insertion population in the ecotype Ler (Speulman et al. 1999), and was positioned at approximately 775 nucleotides after the translational start of the gene (921 nucleotides long), corresponding to the C-terminal region beyond the AP2 domain in the protein. Progenies from this line were genotyped by PCR to identify homozygous and heterozygous plants. When compared to wild type plants, the homo- and heterozygote progeny lines did not reveal fully penetrant major alterations in the general aerial architecture in mature stages or in early root development (first 3 weeks) that could be associated with the presence of the insert.

Overexpression of $B O L$ in Arabidopsis induces formation of ectopic calli in vitro

Since the insertion mutant allele studied did not provide further information about the gene function, the Arabidopsis and tobacco overexpression lines
PCR shows higher accumulation of the BOL transcript in different tissues of the activation mutant than in wild type tissues. R, roots; RL, rosette leaves; CL, cauline leaves; St, stem; $\mathrm{B}$, flower buds; $\mathrm{F}$, flowers

were analyzed in more detail. Additional phenotypes were observed when the $35 S-B O L$ Arabidopsis lines were grown in vitro. Three lines out of four showed callus formation when grown on medium containing kanamycin. Ten days after germination, different tissues from the affected seedlings (i.e. cotyledons, new leaves, hypocotyl) were vitrified (Fig. 5F). Four weeks after germination, the organization of their aerial tissues was lost (Fig. 5G) and root regions, particularly above the tip, had formed callus. Some seedlings were totally converted into green callus (Fig. $5 \mathrm{H}$ ) by this time. One of the callus forming lines, the $35 \mathrm{~S}$ $B O L$-A line representing the most severe phenotype (with multiple loci), showed callus formation also on media lacking kanamycin. Approximately one-quarter of the $35 S-B O L-A$ seeds produced stunted seedlings that were yellowish/white, and did not form true leaves or a root (Supplementary Fig. 2J). The remaining seedlings developed green cotyledons and started to form true leaves, but 2 weeks after germination their aerial organs were vitrified (Fig. 5J and Supplementary Fig. 2M). After 3-4 weeks, some seedlings were almost completely converted into callus and could not survive when transferred to soil. The phenotype of callus formation was also observed in roots, which were very reduced in length and had very few lateral roots in comparison to wild type plants (Supplementary Fig. 2N and Q), an enhanced phenotype of the original bol-D roots. Green sectors started to form near 35S-BOL-A root tips (shown in Fig. 5I). These sectors were first visible as a few green

\begin{tabular}{|l|lll|}
\hline & Journal : 11103 & Dispatch : 25-7-2006 & Pages : 19 \\
Article No. : 9059 & $\square$ LE & $\square$ TYPESET \\
MS Code : PLAN1755 & $\checkmark_{\mathrm{CP}}$ & $\checkmark$ DISK \\
\hline
\end{tabular}



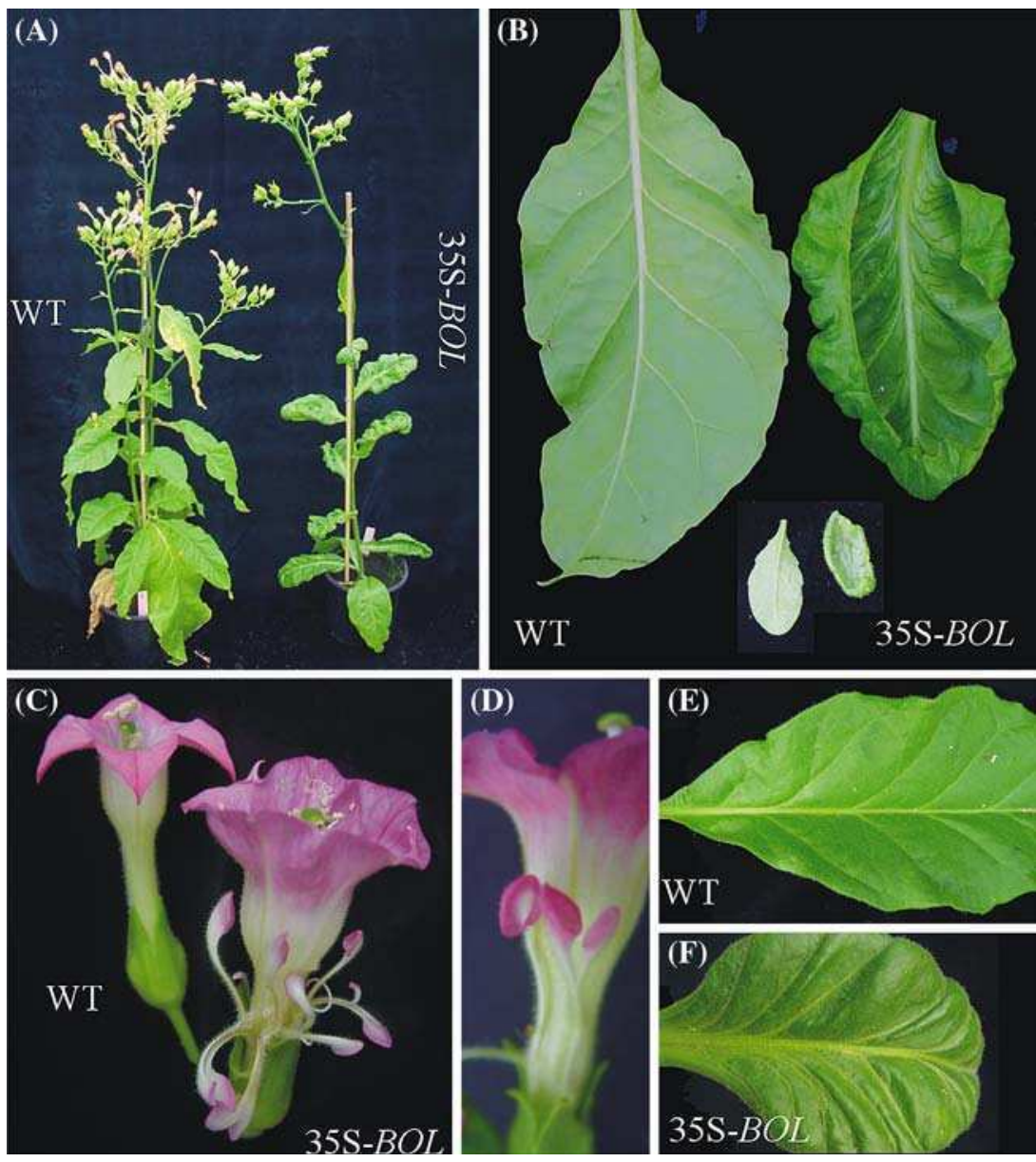

Fig. 4 Phenotype of $35 \mathrm{~S}-\mathrm{BOL}$ tobacco plants. (A) $35 \mathrm{~S}-\mathrm{BOL}$ compared to Wild type plant. The curved leaf phenotype present in the original bol-D mutant is also present in the tobacco transformants. (B, E and $\mathbf{F}$ ) Wild type and $35 \mathrm{~S}-B O L$ tobacco leaves. The positive curvature of the $35 \mathrm{~S}-B O L$ leaf is shown in $\mathbf{B}$. Below, a comparison of the original bol-D (left) and wild type (right) Arabidopsis leaves. The venation pattern of $35 \mathrm{~S}-\mathrm{BOL}$ leaves is disorganized in comparison of wild type leaves ( $\mathbf{E}$ and F). (C and D) Comparison of $35 \mathrm{~S}-B O L$ and wild type flowers. Most 35S-BOL flowers had increased size and some had extra petals developing between the normal petals and sepals. The small ectopic petals were closed or half closed as a tube (D), reminiscent of the wild type corolla cells contrasting with the colorless root, and started to proliferate above the root surface after several days (Supplementary Fig. 2H, I and K). Noteworthy, when the green callus was detached from the root and placed again in medium devoid of hormones, it proliferated and gave rise (at least in one-fourth of the cases) to leaves and later stems and flowers, though roots were rarely observed in these conditions (Fig. 4K and Supplementary Fig. 2L).

This observation of callus formation with shoot identity close to the root tip of $35 S$ - $B O L$-A seedlings led us to study the effect of different hormones on the frequency and time of on the process. This was analyzed by seed germination directly, or seedling transfer after 5 days, to medium supplemented with different hormones. As shown in Table 2, calli initiation was observed after 7-9 days when the seedlings were grown in medium supplemented with brassinosteroids (BL22-23 and EBR) and cytokinins, whereas it required at least 14 days to observe them in untreated seedlings, a $25-50 \%$ reduction in time. More lateral roots developed in auxin treated seedlings, which resulted in a total higher number of calli per seedling. When seedlings were transferred to medium supplemented with hormones after germination, at 11 days after transfer, kinetin treated seedlings had a very defined callus at the root tip (single root) whereas NAA and IAA treated seedlings had many secondary greenish roots that were beginning to fuse with each other (data not shown). Milder 35S$B O L-\mathrm{B}$ and $-\mathrm{C}$ lines produced shoot tissues in the region between the hypocotyl and the root when transferred to medium supplemented with kinetin after being germinated in the presence of IAA (data

\begin{tabular}{|l|lll|}
\hline & Journal : 11103 & Dispatch : 25-7-2006 & Pages : 19 \\
Article No. : $\mathbf{9 0 5 9}$ & $\square$ LE & $\square$ TYPESET \\
MS Code : PLAN1755 & $\varpi_{\text {CP }}$ & $\nwarrow$ DISK \\
\hline
\end{tabular}



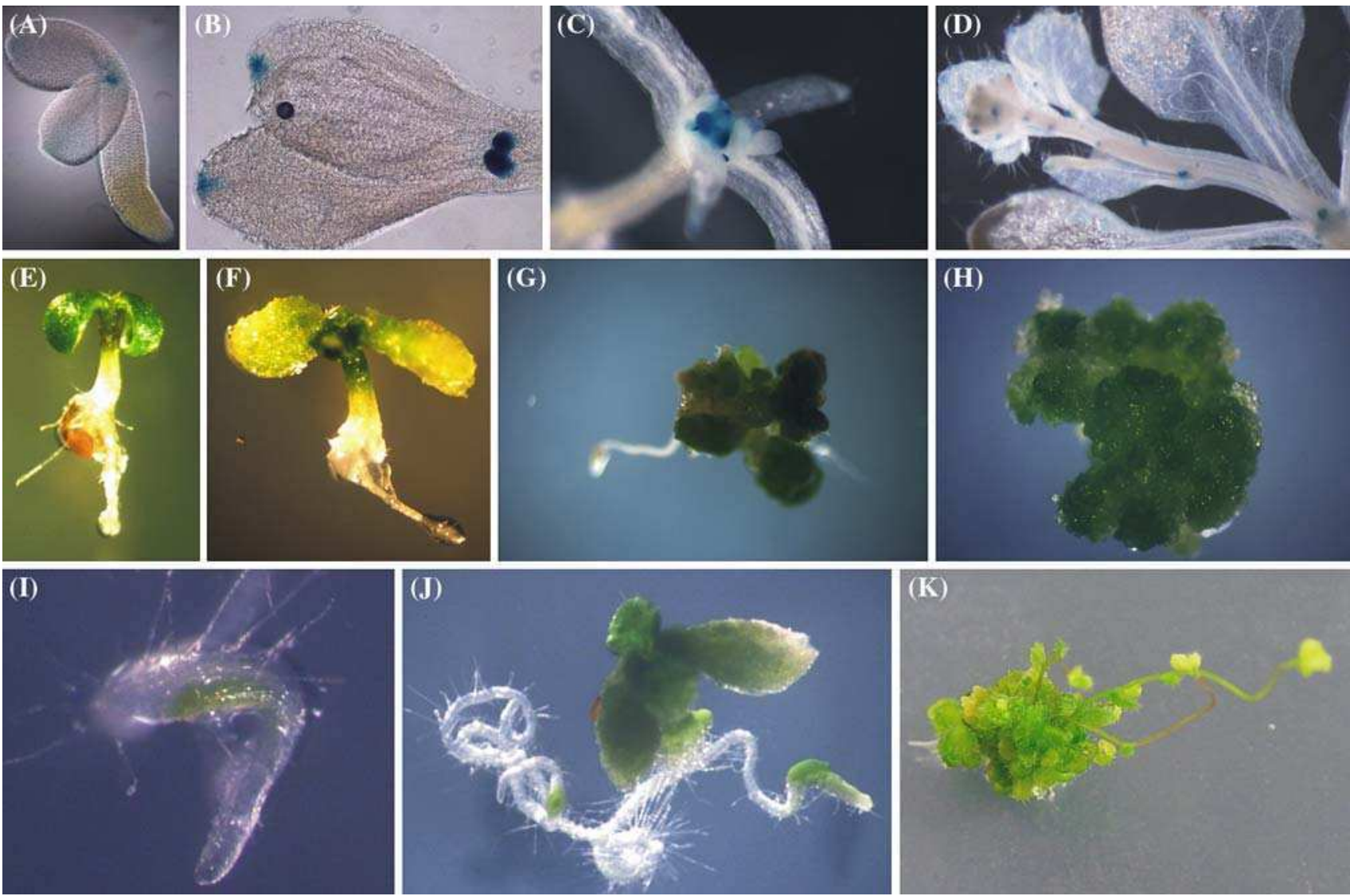

Fig. 5 Callus formation in $35 \mathrm{~S}-B O L$ without the addition of hormones to the medium and X-gluc staining of $B O L$ promoter$G U S$ plants. (A-D) GUS staining of $B O L$ promoter-GUS. (A) One day after germination, seedlings showed staining between the cotyledons. (B) Two- to three-day-old seedlings showed staining of leaf primordia and the tip of the cotyledons. (C) Around 13 days after germination, seedlings showed staining at the tip of the young new leaves, intense staining at leaf primordia and milder staining at the meristem. (D) Flowering plant showing staining at the axillary meristems, young leaf stipules and flower bud internal organs. (E-H) $35 \mathrm{~S}-B O L$ seedlings grown on medium containing kanamycin. (E and $\mathbf{F}$ ) Ten days old $35 \mathrm{~S}-$

$B O L-B$ seedlings: (E) showing alterations in the shape of the cotyledons and (F) showing vitrification in the aerial tissues and thickening of the root tip. ( $\mathbf{G}$ and $\mathbf{H})$ Four weeks old plants, grown for 17 days in kanamycin and transferred afterwards to medium lacking the antibiotic, showing conversion into callus. (G) separate aerial organs and $(\mathbf{H})$ conversion of the whole plant. (I-K) 35S-BOL-A seedlings grown on medium without kanamycin or hormones. (I) Initiation of green sector near the root tip. (J) Conversion of $35 \mathrm{~S}-B O L-\mathrm{A}$ aerial organs and root regions into callus-like tissue. $(\mathbf{K})$ A callus detached from the root started developing shoots, leaves and flowers without the addition of hormones

not shown). This was reminiscent of the features observed in the severe $35 S-B O L-\mathrm{A}$ and was also observed in some bol-D plants directly grown in BAP (Supplementary Fig. 2G). Noteworthy, while callus formation appeared to be enhanced in medium supplemented with $5 \mathrm{uM}$ kinetin, we observed that leaves were insensitive to the treatment, since serrations at the leaf edge shown by wild type plants 4 weeks after germination were not observed in the $35 \mathrm{~S}$ - $B O L$ or bol-D plants (Supplementary Fig. 2F).

\section{Overexpression phenotype of $B O L$ in tobacco}

Tobacco plants overexpressing At $B O L$ were generated and their leaves showed a cupped phenotype (positive curvature, Fig. 4B) and had smaller cells than wild type leaves (data not shown), as occurred in the original bol-D Arabidopsis mutant. Since nuclear DNA content, which can be increased through endoreduplication cycles, is commonly related to cell size (Kondorosi et al. 2000; Sugimoto-Shirasu and Roberts 2003), the DNA content per nucleus was measured in wild type and $35 S-B O L$ tobacco leaves with a flow cytometer. Characteristically, these measurements revealed a relatively higher proportion of $4 \mathrm{C}$ cells in $35 \mathrm{~S}-\mathrm{BOL}$ than wild type mature tobacco leaves (Supplementary Fig. 3).

Moreover, the flowers of the tobacco $35 \mathrm{~S}-B O L$ lines revealed interesting morphological changes. They had broader petals than wild type flowers, with

\begin{tabular}{|l|lll|}
\hline & Journal : 11103 & Dispatch : 25-7-2006 & Pages : 19 \\
Article No. : 9059 & $\square$ LE & $\square$ TYPESET \\
MS Code : PLAN1755 & $\mho_{\mathrm{CP}}$ & $\square$ DISK \\
\hline
\end{tabular}


Table 2 Effect of hormone treatment in the frequency of callus formation at the root tip of $35 \mathrm{~S}-\mathrm{BOL}-\mathrm{A}$ seedlings ${ }^{\mathrm{a}}$

\begin{tabular}{lllr}
\hline Hormone & $\begin{array}{l}\text { Number of seedlings } \\
\text { with callus at Day 7 }\end{array}$ & $\begin{array}{l}\text { Number of seedlings } \\
\text { with callus at Day }\end{array}$ & $\begin{array}{l}\text { Total germinated } \\
\text { seedlings }\end{array}$ \\
\hline EBR 5 nM & $5(71 \%)$ & $7(100 \%)$ & 7 \\
BL22-23 5 nM & $3(42 \%)$ & $7(100 \%)$ & 7 \\
BAP 0.5 uM & $3(25 \%)$ & $10(83 \%)$ & 12 \\
Kin 0.5 uM & $0(0 \%)$ & $4(33 \%)$ & 12 \\
Gib 0.5 uM & $0(0 \%)$ & $1(9 \%)$ & 11 \\
IAA 0.5 uM & $0(0 \%)$ & $0(0 \%)$ & 11 \\
Control & $0(0 \%)$ & $1(9 \%)$ & \\
$\quad$ (no hormone) & & & \\
\hline
\end{tabular}

${ }^{\text {a }}$ The seedlings were germinated directly on medium supplemented with hormones and observed at 7 days and 9 days after germination. The number of seedlings showing visible green sectors (later calli) in the main root is indicated, and in parenthesis the percentage that it represents from the total seedlings assayed (given in the last column)

661 edges curving towards the inner part of the flower 662 rather than the outside in two out of three transfor663 mants (-a and -c, Fig. 4C). Furthermore, these trans664 formants showed an extra whorl of petals, present 665 between the petals and the sepals in most flowers of 666 transformant -a, and some of transformant -c 667 (Fig. 4C). These ectopic petals were smaller than the 668 wild type petals, longitudinally curved and sometimes 669 forming a closed circle, as the normal tobacco fused 670 corolla (Fig. 4D).

671 Effects of $B O L$ activation on the expression of 672 other genes

673 In order to investigate whether $B O L$ overexpression 674 resulted in changes in the expression of other genes that 675 could explain the leaf phenotype, gene expression in bol$676 D$ and wild type Arabidopsis leaves was studied. Leaves 677 were chosen for these experiments because they showed 678 a clear, consistent phenotype that was reproduced by 679 overexpression of the gene in tobacco, suggesting that 680 there could be comparable effects in both plants. RNA 681 from the youngest leaves from 4 weeks old plants was 682 hybridized to Affymetrix Arabidopsis ATH1 Genome 683 Arrays. All genes compared were considered to be dif684 ferentially expressed if the $90 \%$ lower confidence bound 685 of the fold change-further referred as "fold" for sim686 plicity-between experiment and baseline was above 1.3 687 (Median false discovery rate of $0 \%$ ).

688 The genes differentially changed above a threshold 689 of 2 were first analyzed. Genes involved in particular 690 processes were overrepresented either in the up or 691 downregulated groups. Many upregulated genes were 692 related to lipid metabolism and transport, and histone 693 genes were exclusively present among the upregulated 694 genes. On the other hand, genes involved (or puta695 tively involved) in signaling (e.g. calcium-dependent 696 signaling), transcriptional regulation and hormone biosynthesis/signaling were prominently repressed (Table 3). Genes related to stress, transport and metabolism were present to an equal extent in both groups. The highest upregulated genes included lipid related genes, while cell wall remodeling genes were among the genes showing the highest downregulation, changing from present calls in the wild type to absent calls in the mutant. Remarkably, nine auxin responsive genes belonging to the Aux/IAA (three genes: IAA7/ $A X R 2, I A A 17 / A X R 3$, and IAA3/SHY2) and SAUR (Small Auxin Up-regulated RNAs, six genes) families were changed above 2-fold. Interestingly, four of the six changed SAUR genes (At1g29440, At1g29450, At1g29460, At1g29500) belong to a cluster of eight SAURs in chromosome 1 (Scherer 2002) http:// kty12.sci.hokudai.ac.jp/plant_physiol/SAUR.htm), while SHY2 and AXR3 are also located next to each other in the genome (At1g04240 and At1g04250). SAUR proteins are suggested to have a role in auxin signaling involving calcium and calmodulin (Hagen and Guilfoyle 2002). In congruence, many calcium or calmodulin binding genes, including the calcium dependent protein kinase $C P K 32$, were also downregulated (Cheng et al. 2002). The auxin induced genes $T C H 3$ and PBP1 which contain calcium binding motives and interact in a calcium dependent manner with the PINOID kinase, a key component in auxin signaling, were also repressed (Benjamins et al. 2003).

In a deeper survey of the differentially regulated genes due to $B O L$ overexpression, we lowered the threshold to 1.3-fold in order to look for genes with modest changes, which could be still informative about the role of BOL (Supplementary Table I). We were particularly interested in regulatory genes that might have a role in determining cell size, division, hormonal regulation and that could explain the leaf curvature. A selection of relevant genes annotated as cyclins, RBR1, $T C P$, and histones are shown in Table 3.

\begin{tabular}{|l|lll|}
\hline Journal : $\mathbf{1 1 1 0 3}$ & Dispatch : 25-7-2006 & Pages : 19 \\
Article No. : 9059 & $\square$ LE & $\square$ TYPESET \\
MS Code : PLAN1755 & $\checkmark$ CP & $\checkmark$ DISK \\
\hline
\end{tabular}


Table 3 Selected genes with transcript level fold changes more/less than 1.3

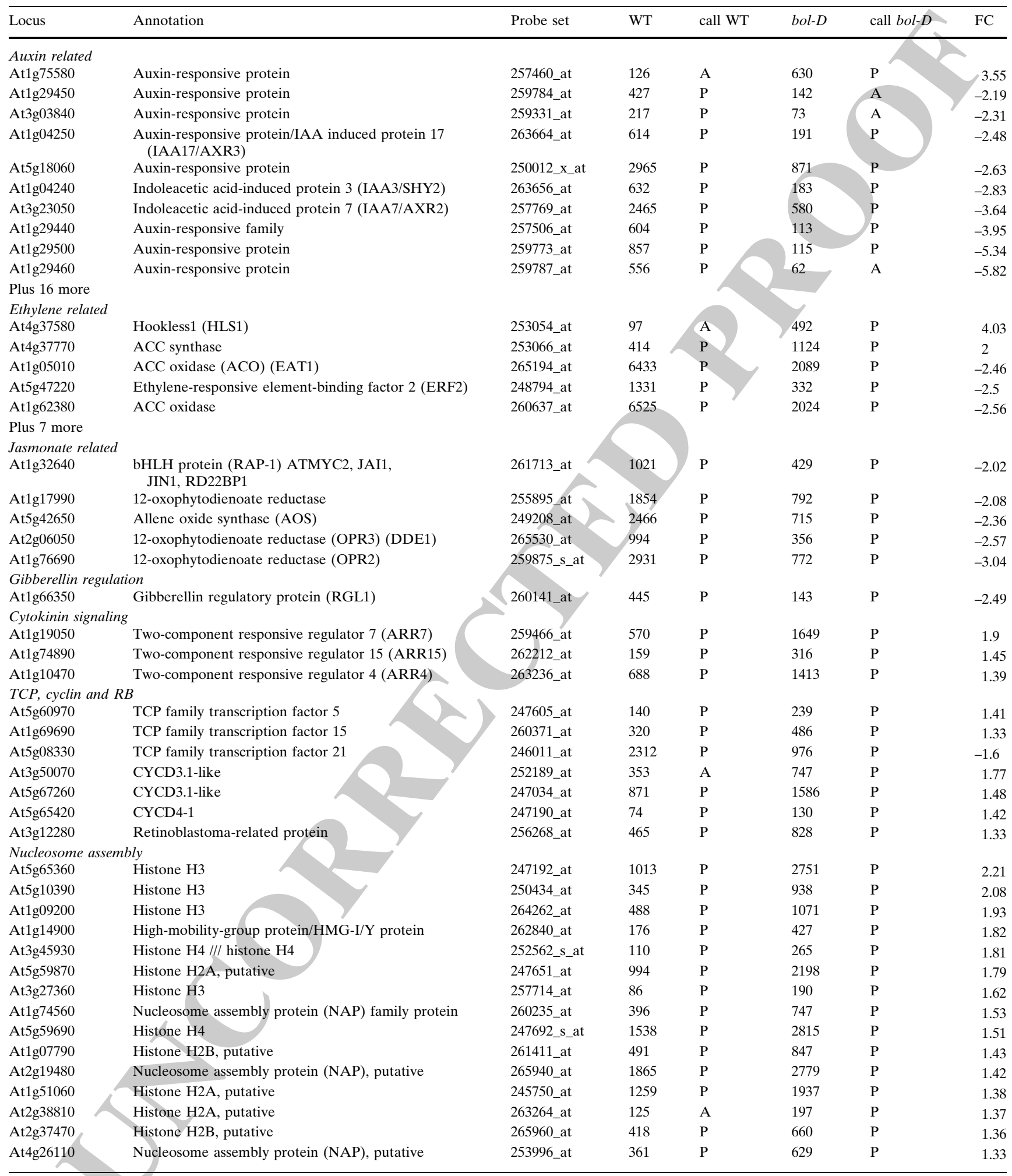

Genes with $90 \%$ lower confidence bound of fold change (FC) more than 1.3. The first three columns describe the TAIR locus (AGI ID), the gene annotation and the Affymetrix probe set. The following columns give the expression value of the gene for the wild type (WT) and bol-D mutant followed by the detection call (present/absent as P/A) and the FC

\begin{tabular}{|l|lll|}
\hline & Journal : 11103 & Dispatch : 25-7-2006 & Pages : 19 \\
Article No. : 9059 & $\square$ LE & $\square$ TYPESET \\
MS Code : PLAN1755 & $\checkmark$ CP & $\square$ DISK \\
\hline
\end{tabular}


In the group of genes changing from 1.3- to 2-fold, many other transcription factors (including MYB, AP2, NAM and WRKY families, and the abaxial cell fate regulator $Y A B B Y 3$ (Siegfried et al. 1999), auxin and ethylene-related genes, and expansin genes were altered significantly. The auxin-related genes with altered expression summed up to a total of 25 (including those above 2-fold). Twelve ethylene-related, seven expansins and three genes involved in cytokinin signaling (two-component responsive regulators) (Hwang et al. 2002), were also altered.

The Supplementary Table II shows a gene ontology classification of all genes showing fold changes above 1.3. A significant enrichment of genes involved in the ribosome, nucleosome, cell wall catabolism, and phosphorylation was observed, as shown in Table 4. All the histone and ribosomal genes altered in expression were upregulated.

\section{Discussion}

$B O L$ affects cell growth, cell number and differentiation

Cell proliferation and differentiation are developmentally regulated in leaves (Donnelly et al. 1999; Desvoyes et al. 2006) that reveal an organized pattern of development from the axillary meristem (Meijer and Murray 2001). To identify genes involved in this process, an activation tagging approach (Marsch-Martinez et al. 2002) was used to identify mutants with altered cell size or number, revealed as changes in leaf morphology. A small sized mutant plant isolated in this screen, named bolita, had petiole-less, small epinastic leaves, and a major reduction in stem elongation. In leaves, both cell expansion and cell proliferation were affected: A reduction of about three-times cell size and twice cell number accounted for the almost six times total area reduction in bol-D leaves when compared to wild type.

The BOLITA gene belongs to the ERF gene subfamily of transcriptional regulators and contains a single AP2 domain. Independent lines containing a $35 S-B O L$ construct reproduced the bol-D phenotype with different degrees of severity in wild type Arabidopsis, which could be due to differences in expression of $B O L$ in the activation tag mutant and in the $35 \mathrm{~S}$ driven overexpressors. The overexpression approach allowed the phenotypic comparison to close homologs that had been studied previously in the same way, like LEAFY PETIOLE (LEP) (van der Graaff et al. 2000) and DRN/ESR1 (Banno et al. 2001; Kirch et al. 2003). The closest homolog of the BOL gene in the Arabidopsis genome is $D R N / E S R 1$, and had therefore been identified as DRN-like. DRN/ESR1 is involved in meristem and lateral organ development. Kirch et al. (2003) reported that plants containing an insertion in the $D R N / E S R$ coding sequences did not show any phenotypic alterations, possibly due to redundancy with $B O L(D R N$-like). However, they also indicate that since $D R N$-like $(B O L)$ is not expressed in the same as DRN/ESR1 (stem cell domain of meristems) their functions might be only partially overlapping. The overexpression phenotypes of $B O L$ and $D R N / E S R 1$ confirm this suggestion. They share similarities that include plant dwarfism, siliques of altered shape and reduced size and formation of green calli in roots, also enhanced by cytokinin application (Banno et al. 2001; Kirch et al. 2003). However, $d r n-D$, also an activation tagging mutant, prematurely arrests organ formation at the shoot meristem: It begins to form radialized lateral organs after producing 4 or 5 leaves (Kirch et al. 2003). In bol-D mutants such radialized organs were not ob-

\begin{tabular}{|c|c|c|c|c|}
\hline \multirow{15}{*}{$\begin{array}{l}\text { Table } 4 \text { Gene ontologies } \\
\text { enriched in the group of genes } \\
\text { with altered expression in } \\
\text { bol-D }\end{array}$} & Gene ontology & $\begin{array}{l}\text { Genes found in } 1144 \\
\text { annotated genes }\end{array}$ & Total in 17457 & $P$ value \\
\hline & Nucleosome & 13 & 74 & 0.000950 \\
\hline & Chromosome organization \& biogenesis & 13 & 72 & 0.000727 \\
\hline & Nucleosome assembly & 15 & 61 & 0.000007 \\
\hline & Nucleolus & 4 & 6 & 0.000247 \\
\hline & Structural constituent of ribosome & 134 & 578 & 0.000000 \\
\hline & Ribosome & 135 & 576 & 0.000000 \\
\hline & Protein biosynthesis & 137 & 780 & 0.000000 \\
\hline & Translational elongation & 11 & 45 & 0.000117 \\
\hline & Large ribosomal unit & 19 & 54 & 0.000000 \\
\hline & Intracellular & 149 & 873 & 0.000000 \\
\hline & Protein amino acid phosphorylation & 91 & 922 & 0.000052 \\
\hline & Protein kinase activity & 62 & 616 & 0.000488 \\
\hline & Chitinase activity & 6 & 14 & 0.000149 \\
\hline & Cell Wall catabolism & 7 & 24 & 0.000656 \\
\hline
\end{tabular}

\begin{tabular}{|l|lll|}
\hline Journal : $\mathbf{1 1 1 0 3}$ & Dispatch : 25-7-2006 & Pages : 19 \\
Article No. : $\mathbf{9 0 5 9}$ & $\square$ LE & $\square$ TYPESET \\
MS Code : PLAN1755 & $\checkmark$ CP & $\square$ DISK \\
\hline
\end{tabular}


served and the meristem did not seem to be affected as in $d r n-D$, since flower buds were observed at a similar time and position as in wild type plants.

$B O L$ transcripts were found in young stamen and petals, embryo and seed (Kirch et al. 2003; de Folter et al. 2004), with expression generally observed in meristematic regions and intensely in organ primordia. Cells in these tissues are small in comparison to cells in mature tissues. Accordingly, $B O L$ confers reduced cell size in mature leaves of both Arabidopsis and tobacco overexpressors, implying a conserved function of $B O L$ in cell growth regulation during development. Moreover, the cell size reduction phenotype was reflected by changes in expression of cell wall remodeling genes and the actin depolymerizing factor $A D F 5$. Cell wall remodeling genes were among the most repressed genes, and the highest downregulated gene was an expansin. Expansins are key regulators of cell wall extension during growth ( $\mathrm{Li}$ et al. 2003), and $A D F$ family members are considered to be key regulators of cell and organ expansion in Arabidopsis (Dong et al. 2001; Smith 2003).

Differentiation programs were also clearly affected as revealed by changes in organ identity. The most conspicuous changes were the development of callus with shoot identity at the root tip, and vitrification of aerial organs in the most severe $B O L$ overexpressor, without the addition of hormones. Milder lines showed also callus formation on aerial parts when grown on medium containing kanamycin, suggesting that the antibiotic triggered the process (probably by reducing chlorophyll and inducing redifferentiation). Remarkably, the abaxial cell fate regulator $Y A B B Y 3$ was downregulated almost 2-fold in bol-D. This polarity gene, required for proper leaf outgrowth, also prevents cells at the leaf margins-the last to differentiate-from reverting to stem cells (Siegfried et al. 1999; Kumaran et al. 2002).

\section{$B O L$ causes changes in the expression of cell cycle} regulators

A relationship with the cell cycle was suggested by the $B O L$ pattern of expression, together with the reduced cell numbers and the leaf curvature phenotype (reproduced in a heterologous species) upon $B O L$ overexpression. Support of this relationship comes from 15 nucleosome components that were upregulated in bol-D leaves. These included histone $H 4$ genes, which are also altered in the Antirrhinum majus cin mutant (Nath et al. 2003) and in CYCD3;1 overexpressors (Riou-Khamlichi et al. 1999). The expression of a large number of ribosomal components was also changed. Both the changes in expression of nucleosome and ribosomal components could be related to the higher proportion of $4 \mathrm{C}$ cells observed in $35 \mathrm{~S}-\mathrm{BOL}$ tobacco leaves. Remarkably, this increase in the $4 \mathrm{C}$ cells in 35S-BOL tobacco leaves had also been observed in tobacco leaves overexpressing both E2Fa and DPa (Kosugi and Ohashi 2003), involved in cell cycle regulation. Additionally, other key features of their phenotypes were markedly similar in both plants: the morphology of their organs, and the small sized cells in leaves.

E2F genes are the final component of the E2F/ cyclin D/retinoblastoma pathway of cell proliferation and differentiation control, where CYCD proteins inhibit RBR1 through phosphorylation, derepressing E2F regulated genes and promoting S-Phase entrance (reviewed in Dewitte and Murray 2003). Remarkably, three cyclin D (CYCD) genes and the single Arabidopsis RBRl gene were upregulated in bol-D, supporting a role for $B O L$ in cell proliferation. A key step in the cell cycle is the G1-S transition, and it is dominantly driven by the CYCD3;1 D type cyclin (Menges et al. 2006). $C Y C D$ genes are expressed in different tissues and cell suspension lines (Menges et al. 2005). CYCD3 genes are activated by cytokinins (Riou-Khamlichi et al. 1999; Gaudin et al. 2000), and are associated to proliferating, undifferentiated cells (reviewed in Dewitte and Murray 2003). During leaf development, $C Y C D$ transcripts are found at the proliferation stage (Beemster et al. 2005), and CYCD3;1 is expressed at the periphery of the shoot meristem and young organ primordia (Dewitte et al. 2003), similarly to BOL. Moreover, some phenotypic features of plants overexpressing CYCD3;1 (Dewitte et al. 2003) were observed in $B O L$ overexpressors. For example, $C Y C D 3 ; 1$ overexpression can bypass the hormone requirement for the growth of Arabidopsis calli (Riou-Khamlichi et al. 1999). Moreover, the leaves of plants overexpressing CYCD3;1 are small, curled, have asymmetries in their venation pattern and their cells have a reduced size (Dewitte et al. 2003). However, while leaves overexpressing CYCD3; 1 showed an increase in cell number, bol- $D$ leaves had less cells. However, in $B O L$ not only $C Y C D 3 s$ but also $R B R 1$ are upregulated. Dewitte and colleagues showed that RBR1 mRNA levels were also upregulated in plants overexpressing $C Y C D 3 ; 1$ suggesting a possible feedback mechanism (Dewitte et al. 2003). $R B R 1$, in contrast to cycD genes, is associated with the promotion of cell differentiation (Huntley et al. 1998; Wildwater et al. 2005). Moreover, it restricts

\begin{tabular}{|c|c|c|c|}
\hline & Journal : 11103 & Dispatch : 25-7-2006 & Pages: 19 \\
\hline 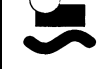 & $\begin{array}{l}\text { Article No. : } 9059 \\
\text { MS Code : PLAN1755 }\end{array}$ & $\begin{array}{l}\square \mathrm{LE} \\
{ }_{\mathrm{CP}}\end{array}$ & $\begin{array}{l}\square \text { TYPESET } \\
\Downarrow \text { DISK }\end{array}$ \\
\hline
\end{tabular}


cell division in the early stages of leaf development, but this effect largely depends on the developmental stage, the tissue and cell type, due to their distinct proliferative potential (Desvoyes et al. 2006). In this context, the reduced cell number observed in bol-D leaves more closely reflects the RBR1 overexpression phenotype.

On the other hand, the "less-cells" phenotype could also be related to alterations in the expression of TCPs. Characterized members of this family of DNA-binding proteins are organ growth modifiers that function in processes related to cell proliferation, either influencing it positively (Type I) or negatively (Type II TCP genes) (Cubas et al. 1999). For example, the Antirrhinum $c y c$ and $c$ in mutants, defective in Type II TCP gene, show ectopic cycD3 expression (Gaudin et al. 2000; Nath et al. 2003). Type I and II TCP genes bind to different motifs in promoters (Cubas et al. 1999; Kosugi and Ohashi 2002; Li et al. 2005). Using the Pattern Match tool from the TAIR database (www.arabidopsis.org), among the CYCD genes, a TCP I binding site was found 1000 upstream of the CYCD4;1 gene (GGCCCAC), and most interestingly, a TCP II binding site upstream of the RBRI gene (GTGGGCCC), both upregulated in bol-D.

In the Arabidopsis jaw and the Antirrhinum cin mutants, the absence of type II TCP gene function causes unrestrained cell division at the edges of leaves (Nath et al. 2003; Palatnik et al. 2003). The result is faster growth at the edge than inside the leaf that leads to a negative curvature phenotype. In bol- $D$ leaves, three TCP genes are affected, and one of the upregulated genes belongs to class II. Accordingly, the phenotype showed by bol-D is exactly opposite to jaw and cin mutants: The edge seems to grow slower than the inner lamina. The altered TCP genes are different from those affected by the jaw miRNA, so their regulation might be different.

Furthermore, post-transcriptional modifications, e.g. protein degradation and phosphorylation among others, are pivotal cell cycle regulatory mechanisms. In fact, a significant enrichment of genes involved in phosphorylation was observed, though it was not further investigated. Therefore, it cannot be ruled out from the present results that these or other cell cycle components are also post-transcriptionally modified.

The perturbations in the normal cell proliferation and differentiation programs observed in different tissues of $B O L$ overexpressors together with the misregulation of the RBR1,CYC-D and TCP genes in Arabidopsis, suggests that even if the changes just reflect a secondary or compensatory response, $B O L$ is clearly capable of affecting proliferation processes.

Interaction of hormonal pathways and $B O L$ expression

Some bol-D phenotypic features, e.g. less lateral roots in bol-D and photomorphogenesis in 35S-BOL-A hypocotyls suggested alterations in hormonal pathways (Bhalerao et al. 2002; Alabadi et al. 2004). However, hormonal treatments at concentrations that induced a response in wild type plants and partial responses on the $B O L$ overexpressors, did not restore the mutant phenotype to wild type. For auxin in particular, the staining of the DR5-GUS reporter was not diminished in the mutant leaves, suggesting at least that the phenotype was not caused by a reduction in auxin content or in auxin transport. The microarray experiment revealed changes in many genes involved in auxin signaling rather than biosynthesis, which could explain why hormone application did not restore the mutant phenotype. Most downregulated early auxin responsive genes from the $S A U R$ and $A u x / I A A$ gene families corresponded to clusters in the genome, and this co-regulation was also observed for the interacting protein pairs TCH3-PBP1 and AXR3-SHY2 (Ouellet et al. 2001; Benjamins et al. 2003), suggesting that auxin signaling was altered. The finding of particular subsets of genes from each auxin responsive family could indicate a role in the mediation of specific responses. Accordingly with perturbations in auxin signaling, the expression of a number of auxin-influenced genes was also affected in bol-D (e.g. cell wall, and ethylene and jasmonate related genes, among others).

Dark-grown 35S-BOL seedlings had short hypocotyls (Fig. 2C) and they showed reduced ACC sensitivity (impaired formation of an exaggerated hook, a feature of the triple response, see supplementary text) (Guzman and Ecker 1990). These features indicated possible alterations in the ethylene pathway. Accordingly, there were changes in the expression of the ethylene related genes ERF2 (ethylene response factor 2), HLS1 (Lehman et al. 1996), and three ACC synthases involved in ethylene biosynthesis. Both brassinosteroid and cytokinin treatments shortened the time at which green calli appeared at the $35 \mathrm{~S}$ $B O L$-A root tip (Table 2). Cytokinin treatments had been reported to enhance shoot formation in roots of DRN/ESR1 overexpressors (Banno et al. 2001), but the effect of brassinosteroids was not reported. Since brassinosteroids have been suggested to alter the ratio
967

968

969

970

971

972

973

974

975

976

977

978

979

980

981

982

983

984

985

986

987

988

989

990

991

992

993

994

995

996

997

998

999

1000

1001

1002

1003

1004

1005

1006

1007

1008

1009

1010

1011

1012

\begin{tabular}{|l|lll|}
\hline & Journal : 11103 & Dispatch : 25-7-2006 & Pages : 19 \\
Article No. : 9059 & $\square$ LE & $\square$ TYPESET \\
MS Code : PLAN1755 & $\mho_{\text {CP }}$ & $\square$ DISK \\
\hline
\end{tabular}


1013 of cytokinin:auxin, this could explain the effect of 1014 brassinosteroids enhancing callus formation. How1015 ever, a lack of response to cytokinins in leaves was 1016

observed in all overexpressors, which could suggest that the cytokinin signaling in this tissue was impaired. Three ARR genes (two-component responsive regulator genes involved in cytokinin signaling) were affected in bol-D leaves (Kiba et al. 2003b; To et al. 2004). Remarkably, two of them, ARR4 and ARR15, have been characterized and have opposite effects, promoting or reducing sensitivity to exogenously applied cytokinin, respectively (Osakabe 2002; Kiba et al. 2003a).

Gibberellins specifically enhanced bol-D petal and anther elongation, a feature similar to gibberellin deficient mutant plants. However, young leaves showed the downregulation of the RGL1 gene (a negative modulator of gibberellin response) (Wen and Chang 2002), reflecting a more general imbalance in the gibberellin pathway. Interestingly, $L E P$, a closely related gene to $B O L$, is a positive regulator of GA-induced germination (Ward et al. 2006).

Finally, imbalances in the jasmonic acid pathway in bol- $D$ leaves were also revealed by the microarray analysis. The jasmonic acid response mediator $M Y C 2 /$ JAIl (Berger et al. 1996), and four jasmonic acid biosynthetic enzymes (Table 3) were downregulated, including the auxin induced oxide synthase ( $A O S$ ) gene that is a major control point in octadecanoid signaling (Laudert and Weiler 1998; Tiryaki and Staswick 2002).

Notably, regulatory genes involved in the different hormonal pathways were affected. Therefore, $B O L$ might connect these diverse pathways, though the gene itself did not seem to be directly regulated by short hormonal treatments in young seedlings (data not shown). On the other hand, given the complex interplay between plant hormones, this could be an indirect effect from alterations in a single hormonal pathway (e.g. auxin or cytokinin signaling) (Van Zhong and Burns 2003; De Paepe et al. 2004). The expression changes displayed could also reflect a secondary alteration caused by $B O L$ misexpression, but they are indications of $B O L$ influence on them.

\section{$B O L$ influences flower organ development}

Both the expression pattern and the typical flower phenotypes obseryed in Arabidopsis and tobacco overexpressors suggested that $B O L$ is also involved in floral organ development. Even though young petals and stamens are part of the usual expression pattern of the gene, $B O L$ overexpression has an effect on them, which could be caused by ectopic expression. $35 S-B O L$ floral organs are altered in shape and size in both plants, with greenish petals in Arabidopsis that indicate alteration in organ identity. Moreover, the role of $B O L$ in floral organ development is strongly supported by the appearance of a new petal whorl in the $35 S-B O L$ tobacco flowers. In this way, the comparison of the overall 35S-BOL tobacco and Arabidopsis phenotypes suggest both the presence of conserved $B O L$ interactions that lead to similar phenotypes, and provides indications of new interactions in flower development.

Integrated view of the role of $B O L$ in organ development

The $B O L$ overexpression phenotype and the global expression data together suggest that $B O L$ modulates cell growth and affects proliferation/differentiation processes. BOL overexpression also had effect in the expression of genes involved in auxin and cytokinin signaling and other hormonal pathways revealing the possibility that the effects of BOL are related to one or more hormonal signaling cascades. This is not unlikely, since there are many interconnections between different hormones themselves and with the cell cycle (Vogler and Kuhlemeier 2003; Ramirez-Parra et al. 2005). In this regard, the altered expression of three cytokinin signaling regulators (ARRs) and TCPs could be correlated with the three $C Y C D$ and the RBRl genes as a consequence of $B O L$ overexpression. Noteworthy, the contrasting phenotype of arrested growth in certain tissues and excess proliferation on others seen in $B O L$ overexpressors had been also observed in plants overexpressing its close homolog DRN/ESRI. In these plants the formation of lateral organs is arrested in the SAM, but the shoot apex has extra layers of cells, which have lost their stem cell identity (Kirch et al. 2003), while callus with shoot identity proliferates in 35S-ESR1 roots (Banno et al. 2001). Moreover, the shoot regeneration experiments reported by Banno and colleagues suggested that DRN/ESR1 acts synergistically with cytokinins (Banno et al. 2001). Therefore, the proposed role of $B O L$ in proliferation/differentiation pathways possibly linked with hormones could be a basic function shared by $D R N / E S R 1$ and $B O L$. Variations, e.g. in the expression pattern and/or certain gene interactions, could account for the differences in their individual roles during development.

Organ development proceeds through different stages that involve the concerted operation of prolif-
1076

1077

1078

1079

1080

1081

1082

1083

1084

1085

1086

1087

1088

1089

1090

1091

1092

1093

1094

1095

1096

1097

1098

1099

1100

1101

1102

1103

1104

1105

1106

1107

1108

1109

1110

1111

1112

1113

1114

\begin{tabular}{|l|lll|}
\hline & Journal : 11103 & Dispatch : 25-7-2006 & Pages : 19 \\
Article No. : 9059 & $\square_{\text {LE }}$ & $\square$ TYPESET \\
MS Code : PLAN1755 & $\mho_{\text {CP }}$ & $\checkmark$ DISK \\
\hline
\end{tabular}


1115

1116

1117

1118

1119

1120

1121

1122

1123

1124

1125

1126

1127

1128

1129

1130

1131

1132

1133

1134

1135

1136

1137

1138

1139

1140

1141

1142

1143

1144

1145

1146

1147

1148

1149

1150

1151

1152

1153

1154

1155

1156

1157

1158

1159

1160

1161

1162

1163

1164

1165

1166

1167

1168

1169

1170

1171 eration, expansion and differentiation processes (Beemster et al. 2005). Each process is temporally and spatially controlled, and the action of components like the CYCDs, RBR1 and TCPs are required for their correct succession to give rise to the final shape and size of an organ. BOL, most likely together with other genes, including some hormone signaling regulators (i.e. ARRs), is involved in the initiation of the proliferation-differentiation process from meristematic zones like the organ primordia that develops into lateral organs such as the leaf.

Acknowledgements We thank Robert Sevenier, Sacco de Vries and Cathy Albracht, Kim Boutilier, Asaph Aharoni, and Gert van Arkel for useful suggestions, discussions and help with materials, and Jeroen Peters and Wim Dirkse for technical help with the flow cytometry experiment. We are grateful to Jose Feijo and Margarida Oliveira as organizers of the 2004 EMBO course on Development at Oeiras, Portugal, and Assaf Zemach for collaboration during the global gene expression analysis. Isabelle Bertin is thanked for technical assistance, and Daan Jaspers and Gerrit Stunnenberg for plant care. J.D.B. was supported by fellowship SFRH/BPD/3619/2000 from Fundacão para a Ciência e a Tecnologia. S.D. and A.K. were supported by fellowships from WOTRO-NWO.

\section{References}

Aida M, Beis D, Heidstra R, Willemsen V, Blilou I, Galinha C, Nussaume L, Noh Y-S, Amasino R, Scheres B (2004) The PLETHORA genes mediate patterning of the Arabidopsis root stem cell niche. Cell 119:109-120

Alabadi D, Gil J, Blazquez MA, Garcia-Martinez JL (2004) Gibberellins repress photomorphogenesis in darkness. Plant Physiol 134:1050-1057

Allen MD, Yamasaki K, Ohme-Takagi M, Tateno M, Suzuki M (1998) A novel mode of DNA recognition by a beta-sheet revealed by the solution structure of the GCC-box binding domain in complex with DNA. EMBO J 17:5484-5496

Alonso JM, Stepanova AN, Leisse TJ, Kim CJ, Chen H, Shinn P, Stevenson DK, Zimmerman J, Barajas P, Cheuk R, Gadrinab C, Heller C, Jeske A, Koesema E, Meyers CC, Parker H, Prednis L, Ansari Y, Choy N, Deen H, Geralt M, Hazari N, Hom E, Karnes M, Mulholland C, Ndubaku R, Schmidt I, Guzman P, Aguilar-Henonin L, Schmid M, Weigel D, Carter DE, Marchand T, Risseeuw E, Brogden D, Zeko A, Crosby WL, Berry CC, Ecker JR (2003) Genome-wide insertional mutagenesis of Arabidopsis thaliana. Science 301:653-657

Altschul SF, Madden TL, Schaffer AA, Zhang J, Zhang Z, Miller W, Lipman DJ (1997) Gapped BLAST and PSIBLAST: a new generation of protein database search programs. Nucleic Acids Res 25:3389-3402

Banno H, Ikeda Y, Niu QW, Chua NH (2001) Overexpression of Arabidopsis ESR1 induces initiation of shoot regeneration. Plant Cell 13:2609-2618

Beemster GTS, De Veylder L, Vercruysse S, West G, Rombaut D, Van Hummelen P, Galichet A, Gruissem W, Inze D, Vuylsteke M (2005) Genome-wide analysis of gene expression profiles associated with cell cycle transitions in growing organs of Arabidopsis. Plant Physiol 138:734-743
Benjamins R, Ampudia CSG, Hooykaas PJJ, Offringa R (2003) PINOID-mediated signaling involves calcium-binding proteins. Plant Physiol 132:1623-1630

Berger S, Bell E, Mullet JE (1996) Two methyl jasmonateinsensitive mutants show altered expression of AtVsp in response to methyl jasmonate and wounding. Plant Physiol 111:525-531

Bhalerao RP, Eklof J, Ljung K, Marchant A, Bennett M, Sandberg G (2002) Shoot-derived auxin is essential for early lateral root emergence in Arabidopsis seedlings. Plant $\mathbf{J}$ 29:325-332

Cheng S-H, Willmann MR, Chen H-C, Sheen J (2002) Calcium signaling through protein kinases. The arabidopsis calciumdependent protein kinase gene family. Plant Physiol 129:469-485

Choe S, Tanaka A, Noguchi T, Fujioka S, Takatsuto S, Ross AS, Tax FE, Yoshida S, Feldmann KA (2000) Lesions in the sterol $\Delta^{7}$ reductase gene of Arabidopsis cause dwarfism due to a block in brassinosteroid biosynthesis. Plant J 21:431-443

Clough SJ, Bent AF (1998) Floral dip: a simplified method forAgrobacterium-mediated transformation of Arabidopsis thaliana. Plant J 16:735-743

Cubas P, Lauter N, Doebley J, Coen E (1999) The TCP domain: a motif found in proteins regulating plant growth and development. Plant J 18:215-222

de Folter S, Busscher J, Colombo L, Losa A, Angenent GC (2004) Transcript profiling of transcription factor genes during silique development in Arabidopsis. Plant Mol Biol 56:351-366

De Paepe A, Vuylsteke M, Van Hummelen P, Zabeau M, Van Der Straeten D (2004) Transcriptional profiling by cDNAAFLP and microarray analysis reveals novel insights into the early response to ethylene in Arabidopsis. Plant $\mathbf{J}$ 39:537-559

Desvoyes B, Ramirez-Parra E, Xie Q, Chua N-H, Gutierrez C (2006) Cell type-specific role of the retinoblastoma/E2F pathway during Arabidopsis leaf development. Plant Physiol 140:67-80

Dewitte W, Murray JAH (2003) The plant cell cycle. Annu Rev Plant Biol 54:235-264

Dewitte W, Riou-Khamlichi C, Scofield S, Healy JMS, Jacqmard A, Kilby NJ, Murray JAH (2003) Altered cell cycle distribution, hyperplasia, and inhibited differentiation in Arabidopsis caused by the D-type cyclin CYCD3. Plant Cell 15:79-92

Dong C-H, Xia G-X, Hong Y, Ramachandran S, Kost B, Chua N-H (2001) ADF proteins are involved in the control of flowering and regulate F-Actin organization, cell expansion, and organ growth in Arabidopsis. Plant Cell 13:1333-1346

Donnelly PM, Bonetta D, Tsukaya H, Dengler RE, Dengler NG (1999) Cell cycling and cell enlargement in developing leaves of Arabidopsis. Dev Biol 215:407-419

Ebel C, Mariconti L, Gruissem W (2004) Plant retinoblastoma homologues control nuclear proliferation in the female gametophyte. Nature 429:776-780

Engelen FA, Molthoff JW, Conner AJ, Nap JP, Pereira A, Stiekema WJ (1995) pBINPLUS: an improved plant transformation vector based on pBIN19. Transgenic Res 4:288-290

Fleming AJ (2006) The co-ordination of cell division, differentiation and morphogenesis in the shoot apical meristem: a perspective. J Exp Bot 57:25-32

Fujimoto SY, Ohta M, Usui A, Shinshi H, Ohme-Takagi M (2000) Arabidopsis ethylene-responsive element binding factors act as transcriptional activators or repressors of GCC box-mediated gene expression. Plant Cell 12:393-404

Gallaher SR (1992) GUS protocols: using the GUS gene as a reporter of gene expression. Academic Press, INC
1172

1173

1174

1175

1176

1177

1178

1179

1180

1181

1182

1183

1184

1185

1186

1187

1188

1189

1190

1191

1192

1193

1194

1195

1196

1197

1198

1199

1200

1201

1202

1203

1204

1205

1206

1207

1208

1209

1210

1211

1212

1213

1214

1215

1216

1217

1218

1219

1220

1221

1222

1223

1224

1225

1226

1227

1228

1229

1230

1231

1232

1233

1234

1235

1236

1237

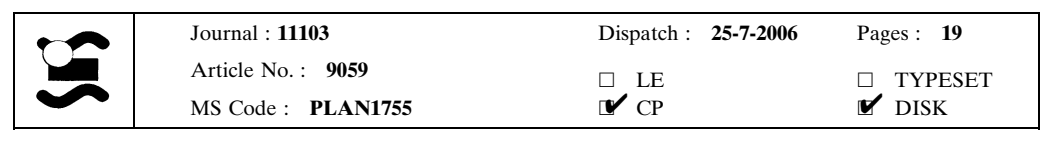


Gaudin V, Lunness PA, Fobert PR, Towers M, Riou-Khamlichi C, Murray JAH, Coen E, Doonan JH (2000) The expression of D-Cyclin genes defines distinct developmental zones in Snapdragon apical meristems and is locally regulated by the Cycloidea gene. Plant Physiol 122:1137-1148

Guzman P, Ecker JR (1990) Exploiting the triple response of Arabidopsis to identify ethylene-related mutants. Plant Cell 2:513-523

Hagen G, Guilfoyle T (2002) Auxin-responsive gene expression: genes, promoters and regulatory factors. Plant Mol Biol 49:373-385

Helliwell CA, Sheldon CC, Olive MR, Walker AR, Zeevaart JAD, Peacock WJ, Dennis ES (1998) Cloning of the Arabidopsis ent-kaurene oxidase gene GA3. PNAS 95:9019-9024

Horsch RB, Fry JE, Hoffmann NL, Eichholtz D, Rogers SG, Fraley RT (1985) A simple and general method for transferring genes into plants. Science 227:1129-1231

$\mathrm{Hu}$ Y, Xie Q, Chua N-H (2003) The Arabidopsis auxin-inducible gene ARGOS controls lateral organ size. Plant Cell 15:1951-1961

Huntley R, Healy S, Freeman D, Lavender P, de Jager S, Greenwood J, Makker J, Walker E, Jackman M, Xie Q, Bannister AJ, Kouzarides T, Gutierrez C, Doonan JH, Murray JAH (1998) The maize retinoblastoma protein homologue $\mathrm{ZmRb}-1$ is regulated during leaf development and displays conserved interactions with $\mathrm{G} 1 / \mathrm{S}$ regulators and plant cyclin D (CycD) proteins. Plant Mol Biol 37:155-169

Hwang I, Chen H-C, Sheen J (2002) Two-component signal transduction pathways in Arabidopsis. Plant Physiol 129:500-515

Kiba T, Yamada H, Sato S, Kato T, Tabata S, Yamashino T, Mizuno T (2003a) The Type-A response regulator, ARR15, acts as a negative regulator in the cytokinin-mediated signal transduction in Arabidopsis thaliana. Plant Cell Physiol 44:868-874

Kiba T, Yamada H, Sato S, Kato T, Tabata S, Yamashino T, Mizuno T (2003b) The Type-A response regulator, ARR15, acts as a negative regulator in the cytokinin-mediated signal transduction in Arabidopsis thaliana 10.1093/pcp/pcg108. Plant Cell Physiol 44:868-874

Kieber JJ, Rothenberg M, Roman G, Feldmann KA, Ecker JR (1993) CTR1, a negative regulator of the ethylene response pathway in arabidopsis, encodes a member of the Raf family of protein kinases. Cell 72:427-441

Kim S, Soltis PS, Wall K, Soltis DE (2006) Phylogeny and domain evolution in the APETALA2-like gene family. Mol Biol Evol 23:107-120

Kirch T, Simon R, Grunewald M, Werr W (2003) The DORNROSCHEN/ENHANCER OF SHOOT REGENERATION1 Gene of Arabidopsis acts in the control of meristem cell fate and lateral organ development. Plant Cell 15:694705

Klahre U, Noguchi T, Fujioka S, Takatsuto S, Yokota T, Nomura T, Yoshida S, Chua N-H (1998) The Arabidopsis DIMINUTO/DWARF1 gene encodes a protein involved in steroid synthesis. Plant Cell 10:1677-1690

Kondorosi E, Roudier F, Gendreau E (2000) Plant cell-size control: growing by ploidy? . Curr Opin Plant Biol 3:488-492

Kosugi S, Ohashi Y (2002) DNA binding and dimerization specificity and potential targets for the TCP protein family. Plant J 30:337-348

Kosugi S, Ohashi Y (2003) Constitutive E2F expression in tobacco plants exhibits altered cell cycle control and morphological change in a cell type-specific manner. Plant Physiol 132:2012-2022
Kuhlemeier C, Reinhardt D (2001) Auxin and phyllotaxis. Trends Plant Sci 6:187-189

Kumaran MK, Bowman JL, Sundaresan V (2002) YABBY polarity genes mediate the repression of KNOX homeobox genes in Arabidopsis. Plant Cell 14:2761-2770

Laudert D, Weiler EW (1998) Allene oxide synthase: a major control point in Arabidopsis thaliana octadecanoid signalling. Plant J 15:675-684

Lehman A, Black R, Ecker JR (1996) HOOKLESS1, an ethylene response gene, is required for differential cell elongation in the Arabidopsis hypocotyl. Cell 85:183-194

Leibfried A, To JPC, Busch W, Stehling S, Kehle A, Demar M, Kieber JJ, Lohmann JU (2005) WUSCHEL controls meristem function by direct regulation of cytokinin-inducible response regulators. Nature 438:1172-1175

Liu Y-G, Whittier RF (1995) Thermal asymmetric interlaced PCR: automatable amplification and sequencing of insert end fragments from $\mathrm{P} 1$ and YAC clones for chromosome walking. Genomics 25:674-681

Li C, Wong WH (2001a) Model-based analysis of oligonucleotide arrays: model validation, design issues and standard error application. Genome Biol 2:r0032.0031-r0032.0011

Li C, Wong WH (2001b) Model-based analysis of oligonucleotide arrays: expression index computation and outlier detection. PNAS 98:31-36

Li Y, Jones L, McQueen-Mason S (2003) Expansins and cell growth. Curr Opin Plant Biol 6:603-610

Li C, Potuschak T, Colon-Carmona A, Gutierrez RA, Doerner P (2005) Arabidopsis TCP20 links regulation of growth and cell division control pathways. PNAS 102:12978-12983

Magnani E, Sjolander K, Hake S (2004) From endonucleases to transcription factors: evolution of the AP2 DNA binding domain in plants. Plant Cell 16:2265-2277

Marsch-Martinez N, Greco R, Van Arkel G, Herrera-Estrella L, Pereira A (2002) Activation tagging using the En-I maize transposon system in Arabidopsis. Plant Physiol 129:1544-1556

Meijer M, Murray JAH (2001) Cell cycle controls and the development of plant form. Curr Opin Plant Biol 4:44-49

Menges M, de Jager SM, Gruissem W, Murray JAH (2005) Global analysis of the core cell cycle regulators of Arabidopsis identifies novel genes, reveals multiple and highly specific profiles of expression and provides a coherent model for plant cell cycle control. Plant J 41:546-566

Menges M, Samland AK, Planchais S, Murray JAH (2006) The D-type cyclin CYCD3;1 is limiting for the G1-to-S-phase transition in Arabidopsis. Plant Cell 18:893-906

Mizukami Y (2001) A matter of size: developmental control of organ size in plants. Curr Opin Plant Biol 4:533-539

Mizukami Y, Fischer RL (2000) Plant organ size control: AINTEGUMENTA regulates growth and cell numbers during organogenesis. PNAS 97:942-947

Mlynarova L, Loonen A, Heldens J, Jansen RC, Keizer P, Stiekema WJ, Nap JP (1994) Reduced position effect in mature transgenic plants conferred by the chicken lysozyme matrix-associated region. Plant Cell 6:417-426

Nakano T, Suzuki K, Fujimura T, Shinshi H (2006) Genomewide analysis of the ERF gene family in Arabidopsis and rice. Plant Physiol 140:411-432

Nath U, Crawford BCW, Carpenter R, Coen E (2003) Genetic control of surface curvature. Science 299:1404-1407

Okamuro JK, Caster B, Villarroel R, Van Montagu M, Jofuku KD (1997) The AP2 domain of APETALA2 defines a large new family of DNA binding proteins in Arabidopsis. PNAS 94:7076-7081
1303

1304

1305

1306

1307

1308

1309

1310

1311

1312

1313

1314

1315

1316

1317

1318

1319

1320

1321

1322

1323

1324

1325

1326

1327

1328

1329

1330

1331

1332

1333

1334

1335

1336

1337

1338

1339

1340

1341

1342

1343

1344

1345

1346

1347

1348

1349

1350

1351

1352

1353

1354

1355

1356

1357

1358

1359

1360

1361

1362

1363

1364

1365

1366

1367

\begin{tabular}{|l|lll|}
\hline Journal : 11103 & Dispatch : 25-7-2006 & Pages : 19 \\
Article No. : 9059 & $\square$ LE & $\square$ TYPESET \\
MS Code : PLAN1755 & $\checkmark$ CP & $\checkmark$ DISK \\
\hline
\end{tabular}


Osakabe Y, Miyate S, Urao T, Seki M, Shinozaki K, YamaguchiShinozaki K (2002) Overexpression of Arabidopsis response regulators, ARR4/ATRR1/IBC7 and ARR8/ ATRR3, alters cytokinin responses differentially in the shoot and in callus formation. Biochem Biophys Res Commun 293:806-815

Ouellet F, Overvoorde PJ, Theologis A (2001) IAA17/AXR3: biochemical insight into an auxin mutant phenotype. Plant Cell 13:829-841

Palatnik J, Allen E, Wu X, Schommer C, Schwab R, Carrington J, Weigel D (2003) Control of leaf morphogenesis by microRNAs. Nature 425:257-263

Ramirez-Parra E, Desvoyes B, Gutierrez C (2005) Balance between cell division and differentiation during plant development. Int J Dev Biol 49:467-477

Riechmann J, Meyerowitz E (1998) The AP2/EREBP family of plant transcription factors. Biol Chem 379:633-646

Riechmann JL, Heard J, Martin G, Reuber L, Jiang C, Keddie J, Adam L, Pineda O, Ratcliffe OJ, Samaha RR, Creelman R, Pilgrim M, Broun P, Zhang JZ, Ghandehari D, Sherman BK, Yu G (2000) Arabidopsis transcription factors: genomewide comparative analysis among eukaryotes. Science 290:2105-2110

Riou-Khamlichi C, Huntley R, Jacqmard A, Murray JAH (1999) Cytokinin activation of Arabidopsis cell division through a D-type cyclin. Science 283:1541-1544

Sakuma Y, Liu Q, Dubouzet JG, Abe H, Shinozaki K, Yamaguchi-Shinozaki K (2002) DNA-binding specificity of the ERF/AP2 domain of Arabidopsis DREBs, transcription factors involved in dehydration- and cold-inducible gene expression. Biochem Biophys Res Commun 290:998-1009

Scherer GF (2002) Secondary messengers and phospholipase A2 in auxin signal transduction. Plant Mol Biol 49:357-372

Schrick K, Fujioka S, Takatsuto S, Stierhof Y-D, Stransky H, Yoshida S, Jurgens G (2004) A link between sterol biosynthesis, the cell wall, and cellulose in Arabidopsis. Plant $\mathrm{J}$ 38:227-243

Siegfried K, Eshed Y, Baum S, Otsuga D, Drews G, Bowman J (1999) Members of the YABBY gene family specify abaxial cell fate in Arabidopsis. Development 126:4117-4128

Smith LG (2003) Cytoskeletal control of plant cell shape: getting the fine points. Curr Opin Plant Biol 6:63-73

Speulman E, Metz PLJ, van Arkel G, te Lintel Hekkert B, Stiekema WJ, Pereira A (1999) A two-component enhancer-inhibitor transposon mutagenesis system for functional analysis of the Arabidopsis genome. Plant Cell 11:1853-1866

Sugimoto-Shirasu K, Roberts K (2003) "Big it up": endoreduplication and cell-size control in plants. Curr Opin Plant Biol 6:544-553
Timpte CS, Wilson AK, Estelle M (1992) Effects of the axr2 mutation of Arabidopsis on cell shape in hypocotyl and inflorescence. Planta 188:271-278

Tiryaki I, Staswick PE (2002) An Arabidopsis mutant defective in jasmonate response is allelic to the auxin-signaling mutant axr1. Plant Physiol 130:887-894

To JPC, Haberer G, Ferreira FJ, Deruere J, Mason MG, Schaller GE, Alonso JM, Ecker JR, Kieber JJ (2004) Type-A Arabidopsis response regulators are partially redundant negative regulators of cytokinin signaling. Plant Cell 16:658-671

Tsugeki R, Kochieva EZ, Fedoroff N (1996) A transposon insertion in the Arabidopsis SSR16 gene causes an embryodefective lethal mutation. Plant J 10:479-489

Tsukaya H (2005) Leaf shape: genetic controls and environmental factors. Int J Dev Biol 49:547-555

van der Graaff E, Dulk-Ras A, Hooykaas P, Keller B (2000) Activation tagging of the LEAFY PETIOLE gene affects leaf petiole development in Arabidopsis thaliana. Development 127:4971-4980

Van Zhong G, Burns JK (2003) Profiling ethylene-regulated gene expression in Arabidopsis thaliana by microarray analysis. Plant Mol Biol 53:117-131

Verwoerd TC, Dekker BM, Hoekema A (1989) A small-scale procedure for the rapid isolation of plant RNAs. Nucleic Acids Res 17:2362

Vogler H, Kuhlemeier C (2003) Simple hormones but complex signalling. Curr Opin Plant Biol 6:51-56

Ward JM, Smith AM, Shah PK, Galanti SE, Yi H, Demianski AJ, van der Graaff E, Keller B, Neff MM (2006) A new role for the Arabidopsis AP2 transcription factor, LEAFY PETIOLE, in gibberellin-induced germination is revealed by the misexpression of a homologous gene, SOB2/DRNLIKE. Plant Cell 18:29-39

Wasteneys G, Fujita M (2006) Establishing and maintaining axial growth: wall mechanical properties and the cytoskeleton. J Plant Res 119:5-10

Wen C-K, Chang C (2002) Arabidopsis RGL1 encodes a negative regulator of gibberellin responses. Plant Cell 14:87-100

Wildwater M, Campilho A, Perez-Perez JM, Heidstra R, Blilou I, Korthout H, Chatterjee J, Mariconti L, Gruissem W, Scheres B (2005) The RETINOBLASTOMA-RELATED gene regulates stem cell maintenance in Arabidopsis roots. Cell 123:1337-1349

Wilson K, Long D, Swinburne J, Coupland G (1996) A dissociation insertion causes a semidominant mutation that increases expression of TINY, an Arabidopsis gene related to APETALA2. Plant Cell 8:659-671

Zhong S, Li C, Wong W (2003) ChipInfo: software for extracting gene annotation and gene ontology information for microarray analysis. Nucleic Acids Res 31:3483-3486
1418

1419

1420

1421

1422

1423

1424

1425

1426

1427

1428

1429

1430

1431

1432

1433

1434

1435

1436

1437

1438

1439

1440

1441

1442

1443

1444

1445

1446

1447

1448

1449

1450

1451

1452

1453

1454

1455

1456

1457

1458

1459

1460

1461

1462

1463

1464

1465

1466

1467

1468

\begin{tabular}{|l|lll|}
\hline Journal : $\mathbf{1 1 1 0 3}$ & Dispatch : 25-7-2006 & Pages : 19 \\
Article No. : $\mathbf{9 0 5 9}$ & $\square$ LE & $\square$ TYPESET \\
MS Code : PLAN1755 & $\checkmark$ CP & $\square$ DISK \\
\hline
\end{tabular}

